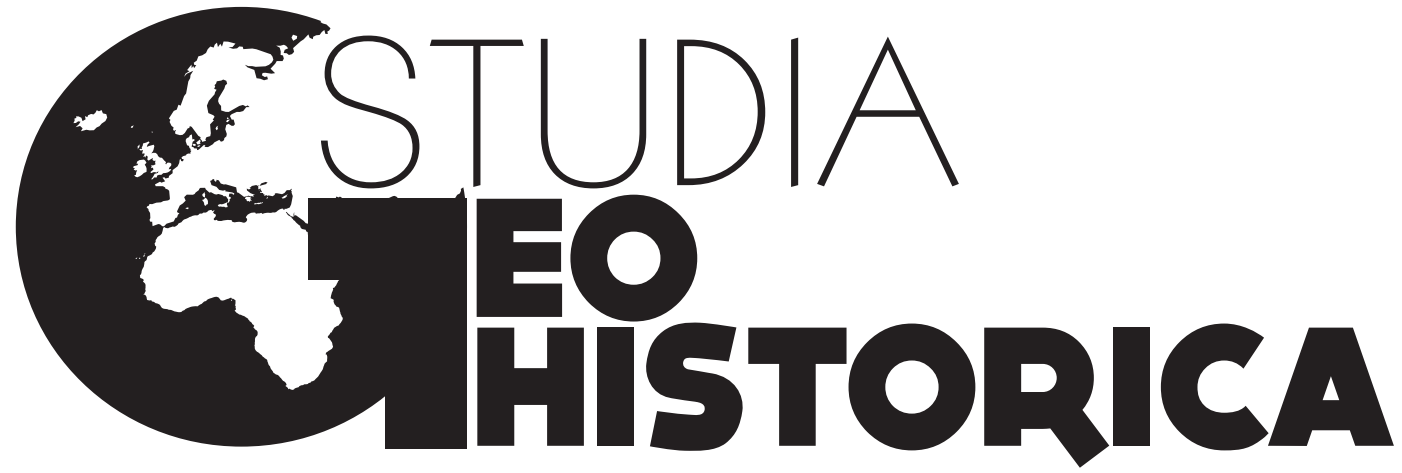

NR 04|2016 ROCZNIK HISTORYCZNO-GEOGRAFICZNY

Fundacja Centrum GeoHistorii • Instytut Geodezji i Kartografii • Instytut Historii KUL

Instytut Historii i Stosunków Międzynarodowych US • Zespół Historii Kartografii przy Instytucie Historii Nauki PAN Biblioteka Główna Uniwersytetu Szczecińskiego 


\section{STUDIA GEOHISTORICA. Rocznik historyczno-geograficzny}

\section{Redakcja}

Bogumił Szady (redaktor naczelny), Beata Konopska, Radosław Skrycki, Tomasz Związek (sekretarz redakcji), Tomasz Panecki

\section{Redakcja językowa i korekta}

Konrad Byzdra

\section{Tłumaczenia}

autorzy, Julia Szołtysek

\section{Rada Naukowa}

Zdzisław Budzyński (Rzeszów), Andrzej Janeczek (Warszawa), Tomasz Jurek (Poznań), Keith Lilley (Belfast/Wielka Brytania), Andrew Pernal (Brandon/Kanada), Tadeusz Siwek (Ostrawa/Czechy), Rostysław Sossa (Kijów/Ukraina), Grzegorz Strauchold (Wrocław), Robert Šimůnek (Praga/Czechy)

\section{Recenzenci tomu 4}

Wojciech Chudziak, Martyna Deszczyńska, Zbigniew Górczak, Maria Jankowska, Iwona Jażdżewska, Andrzej Klonder, Anna Kołodziejczyk, Andrzej Kopiczko, Małgorzata Elżbieta Kowalczyk, Adam Kozak, Joanna Kumor-Mielnik, Mieczysław Kunz, Dariusz Lorek, Wojciech Mielewczyk, Grzegorz Myśliwski, Wiesław Nowosad, Piotr Pabjanek, Marek Radoch,

Małgorzata Rutkiewicz-Hanczewska, Francesco Somaini, Péter Szabó, Piotr Werner, Filip Wolański

\section{Redakcja map}

autorzy, Tomasz Panecki

\section{Adres Redakcji}

Fundacja Centrum GeoHistorii

Redakcja Studia Geohistorica

05-082 Stare Babice, ul. Gen. Tadeusza Kutrzeby 4

\section{Strona internetowa}

studiageohistorica.pl

Wersja drukowana (papierowa) jest wersją pierwotną rocznika Studia Geohistorica

\section{Współwydawcy rocznika}

Biblioteka Główna Uniwersytetu Szczecińskiego, Fundacja Centrum GeoHistorii, Instytut Geodezji i Kartografiii, Instytut Historii Katolickiego Uniwersytetu Lubelskiego Jana Pawła II, Instytut Historii i Stosunków Międzynarodowych Uniwersytetu Szczecińskiego, Zespół Historii Kartografii przy Instytucie Historii Nauki PAN

Rocznik wydawany pod patronatem Komisji Geografii Historycznej przy Polskim Towarzystwie Historycznym Projekt okładki: Jacek Młodożeniec Ilustracja na okładce: Kalisz - Plan miasta i przyległej okolicy autorstwa Ludwiga von Bröckera z 1802 r. Skład i łamanie: Artur Hamryszczak

(C) Copyright by Fundacja Centrum GeoHistorii

ISSN 2300-2875

Nakład 100 egz.

Warszawa 2016 


\section{Spis treści • Contents}

\section{Tradycje geografi historycznej • Traditions of historical geography}

\section{Ludomir Sawicki}

Geografia a krajoznawstwo

(uwagi wstępne Beata Konopska, opracowanie Beata Konopska)

\section{Stanisław Herbst}

Prace nad „Atlasem historycznym Polski”

(uwagi wstępne Henryk Rutkowski, opracowanie Henryk Rutkowski).

\section{Artykuty $\bullet$ Articles and theses}

\section{Elżbieta Kowalczyk-Heyman}

Czym były mazowieckie "płozy"? (uwagi wstępne)

What were the Masovian "płozy"? (Preliminary Remarks)

\section{Robert Klimek}

Ślady średniowiecznej granicy Warmii między Reszlem a Świętą Lipką

Traces of the Medieval Border of Warmia between Reszl and Święta Lipka

\section{Ewa Ziółek}

Relacja Grzegorza Piramowicza o osuszaniu Bagien Pontyjskich za pontyfikatu Piusa VI

Grzegorz Piramowicz's Account of Draining the Pontian Marshes during

the Pontificate of Pope Pius VI

\section{Krzysztof Boroda}

Wpływy z czopowego jako wskaźnik lokalnego zróżnicowania poziomu produkcji

piwa pełnego w miastach Królestwa Polskiego w latach 60. XVI w.

Income from Czopowe as an Indicator of Regional Diversity of Full Beer

Production in the Cities of the Polish Crown in the 1560s

\section{Xavier Rochel}

The End of Gaps and Heathlands in French National Forests, $19^{\text {th }}$ Century.

A Case Study Based on Forest Management Plans

Zanik polan i wrzosowisk we francuskich lasach państwowych w XIX w.

Studium przypadku na podstawie planów zarządzania lasami

\section{Tomasz Figlus}

Typy morfogenetyczne wsi w środkowej Polsce

Morphogenetic Types of Rural Settlements in Central Poland. 
Tomasz Babczyński, Tomasz Kubik, Roman Ptak, Grzegorz Strauchold GIS as a Tool to Analyze the History of Silesia and the Changes in its Political (and Cultural) Geography GIS jako narzędzie do analizy historii Śląska oraz zmian w jego geografii politycznej i kulturowej..

\section{Mateusz Zawadzki}

"Tabella miast, wsi i osad Królestwa Polskiego" jako źródło do badań nad strukturą parafialną województwa lubelskiego

The "Tabella of Towns, Villages and Settlements of the Kingdom of Poland" as the Source for Research into the Parochial Structure of the Lublin Voivodeship

Anna Paulina Orłowska, Bartosz Nowożycki, Grzegorz Pac Handel wołami na terenie Wielkopolski i Śląska w świetle szesnastowiecznego spisu jarmarków i komór celnych The Trade in Oxen on the Territory of the Greater Poland and Silesia in the Light of the $16^{\text {th }}$ Century Description of Annual Fairs and Toll Houses

\section{Recenzje i omówienia $・$ Reviews and discussions}

Historical Atlas of Poland in the $2^{\text {nd }}$ half of the $16^{\text {th }}$ Century: Voivodeships of Cracow, Sandomierz, Lublin, Sieradz, Łęczyca, Rawa, Płock and Mazovia, ed. by Marek Słoń; transl. by Agata Staszewska; Martha A. Brożyna, Peter Lang Edition, Frankfurt am Main 1973-[2014], 4 volumes, XXIX + 1597 pp., illustrations, 27 folded maps

(Alexei Frolov)

Magdolna Szilágyi: On the Road: The History and Archaeology of Medieval Communication Networks in East-Central Europe, Budapest 2014

(Archeolingua Series Minor, 35),

Ss. 254, 89 il. (w tym 30 map i 4 plany miast)

(Ewelina Siemianowska).

The World in a Mirror, Word Maps from the Middle Ages to the Present Day, ed. Jan Parmentier, Museum aan de Stroom, Antwerp 2015, ss. 192, il. $150+25$ (Lucyna Szaniawska)

Kartografia morska i krain nadmorskich, red. R. Skrycki, Instytut Historii

i Stosunków Międzynarodowych Uniwersytetu Szczecińskiego,

Zespół Historii Kartografii Instytutu Historii Nauki PAN, Szczecin 2014;

$24 \times 17$ cm, ss. 204, 54 ryc., 4 tab.

(Jan Rutkowski) 
Алексей А. Фролов, Нина В. Пиотух: Исторический атлас Деревской пятины Новгородской земли (по писцовым книгам письма 1495-1496 годов). В 3 томах: Москва-Санкт-Петербург, Альянс-Архео, 2008.

Т. 1: Исследование и таблицы, ss. 368;

Т. 2: Атлас и справочные материалы, ss. 272;

T. 3: Уездные планы последней четверти XVIII века, ss. 266

(Rostysław Sossa).

Nazwy miejscowe Polski. Historia. Pochodzenie. Zmiany, t. 10-12 (Ra-Rż), red. K. Rymut, B. Czopek-Kopciuch, U. Bijak, [autorzy haseł: U. Bijak, E. Borysiak, J. Chłądzyńska, B. Czopek-Kopciuch, P. Dudek, A. Galasińska, W. Makula-Kosek, I. Nobis, R. Przybytek, P. Swoboda, U. Wójcik, K. Zawodzińska-Bukowiec, Z. Zierhoffer], Polska Akademia Nauk. Instytut Języka Polskiego, Kraków 2015, ss. 160 (t. 10), 146 (t. 11), 168 (t. 12) (Ewa Oronowicz-Kida).

Kit Mayers: The First English Explorer. The Life of Anthony Jenkinson (1529-1611) and his Adventures on Route to the Orient, Devon 2015, ss. 366

(Krystyna Szykuła).

\section{Komunikaty $i$ sprawozdania $\bullet$ Communiques and reports}

Konferencja „Przestrzenne aspekty historycznych badań demograficznych, społecznych i gospodarczych (do 1945 r.)" - Pobierowo, 21-23 października 2015 r.

(Michał Gochna)

„European Social Science History Conference” - Walencja (Hiszpania),

30 marca-2 kwietnia $2016 \mathrm{r}$.

(Michał Gochna)

Zebranie naukowe polskiej sekcji European Society for Environmental History - Warszawa, 16 stycznia $2016 \mathrm{r}$.

(Piotr Guzowski)

„Mapa jako narracja interpretacyjna”. XXIX Ogólnopolska Konferencja Historyków Kartografii - Wrocław, 24-26 września $2015 \mathrm{r}$.

(Jerzy Ostrowski)

Sprawozdanie z konferencji „Województwo poznańskie w XVI w.” - Kościan, 1 lipca 2015 r.

(Michał Stomski).

Sprawozdanie z konferencji „Geografia historyczna. Wyzwania przyszłości” - Łódź, 11-12 czerwca 2015 r.

(Magdalena Deptuła). 204 
Spis treśsi

Pro memoria

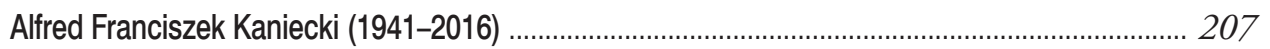

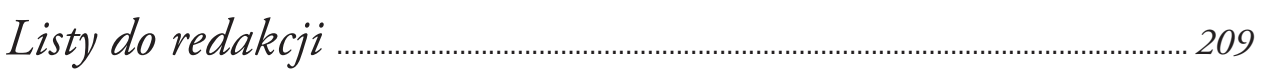

Informacja dla autorów • Guidelines for Authors .................................................... 210 


\title{
Typy morfogenetyczne wsi w środkowej Polsce
}

\author{
Tomasz Figlus
}

\section{Zagadnienia wstępne}

Jednym z najważniejszych zagadnień badawczych geografii historycznej w aspekcie rekonstrukcji krajobrazu kulturowego jest analiza historycznych struktur osadniczych. Szczególnie długą tradycję w tym zakresie wykazują badania poświęcone kwestii rozplanowania wsi ${ }^{1}$. Oprócz kompleksowych studiów autorstwa Bogdana Zaborskiego, Józefa Burszty, Haliny Szulc czy Jana Tkocza $^{2}$ podejmowano w tym zakresie także badania regionalne. Przykładami mogą być prace Marii Kiełczewskiej-Zaleskiej na temat wsi Pomorza Gdańskiego, Haliny Szulc dotyczące m.in. Dolnego Śląska, Opolszczyzny czy Pomorza Zachodniego, Józefa Burszty odnoszące się do Wielkopolski, Marii Dobrowolskiej na temat Małopolski czy Bogumiły Szurowej dotyczące Kielecczyzny ${ }^{3}$. Większość tekstów

\footnotetext{
1 S. Arnold, Geografia historyczna Polski, Warszawa 1951, s. 30-38; J. Tyszkiewicz, Geografia historyczna. Zarys problematyki, Warszawa 2014, s. 71-91.

2 B. Zaborski, 0 ksztattach wsi w Polsce i ich rozmieszczeniu, Kraków 1926 (Prace Komisji Etnograficznej PAU, 1); J. Burstta, Od osady stowiańskiej do wsi wspótczesnej. O tworzeniu się krajobrazu osadniczego ziem polskich i rozplanowaniu wsi, Wrocław 1958; H. Szulc, Morfogeneza osiedli wiejskich w Polsce, Wrocław 1995 (Prace Geograficzne, 163); J. Tkocz, Organizacja przestrzenna wsi w Polsce, Katowice 1998 (Prace Naukowe Uniwersytetu Śląskiego, 1734).
}

${ }^{3}$ M. Kiełczewska-Zaleska, 0 powstaniu i przeobrażeniu ksztaftów wsi Pomorza Gdańskiego, Warszawa 1956 (Prace Geograficzne, 5); H. Szulc, Osiedla podwrocławskie na początku XIX w., Wrocław 1963 (Monografie Śląskie, 5); taż, Typy wsi Śląska Opolskiego na początku XIX w. i ich geneza, Warszawa 1968 (Prace Geograficzne, 66); taż, Morfogenetyczne typy osiedli wiejskich na Pomorzu Zachodnim, Wrocław 1988 (Prace Geograficzne, 149); J. Burszta, Osadnictwo i ksztatty wsi, w: Kultura ludowa Wielkopolski, t. 1, red. J. Burszta, Poznań 1960; M. Dobrowolska, Procesy osadnicze w dorzeczu Wistoki i Białej Dunajcowej w tysiącleciu, Kraków 1985 (Prace Monograficzne WSP, 69); B. Szurowa, Zmiany układu przestrzennego wsi kieleckiej od XIII do połowy XX wieku, Kielce 1998.

4 Szerzej zob.: T. Lalik, Przegląd badań nad historią rozplanowania osad wiejskich w Polsce, Warszawa 1953 (IUA. Seria Prac Własnych, 11); H. Szulc, Badania geograficzno-historyczne osadnictwa wiejskiego w Polsce, „Przegląd Geograficzny”, 55 (3), 1983, s. 647-661; taż, Geografia historyczna osadnictwa wiejskiego w Polsce - kierunki i metody badań oraz perspektywy na przyszłość, „Przegląd Geograficzny”, 75 (3), 2003, s. 335-350. obejmuje jednak mniejszą skalę przestrzenną i czasową, gdyż odnoszą się głównie do określonych typów rozplanowania lub pojedynczych okresów morfogenetycznych ${ }^{4}$. Wiele regionów Polski nie doczekało się kompleksowych studiów morfogenetycznych wsi, czego przykładem jest środkowa Polska, ukształtowana na pograniczu historycznej Wielkopolski, Mazowsza i Małopolski. Oprócz kilku przyczynkarskich prac, w tym studiów osadniczych Jana Dylika i Marka Kotera dla wsi w granicach obecnej Łodzi, Jana Warężaka dla obszaru średniowiecznej kasztelanii łowickiej oraz Stefana Wojtkowiaka dla średniowiecznych wsi łęczyckich, badany obszar nie został pod tym względem opracowany, co też stanowiło asumpt do podjęcia pogłębionych badań w tym zakresie 5 .

$\mathrm{Na}$ potrzeby prowadzonych badań autor pracy zmodyfikował $\mathrm{w}$ zakresie osadnictwa wiejskiego zaproponowane przez Marka Kotera ujęcie terminologiczne ${ }^{6}$. W tym kontekście morfogeneza wsi jawi się jako dział morfologii, nauka traktująca o genezie form krajobrazu, zmierzająca do odtworzenia istniejących obecnie $\mathrm{w}$ formie reliktowej, względnie całkowicie zatartych dawnych układów przestrzennych wsi oraz prześledzenia ewolucji rozplanowania

\footnotetext{
5 J. Dylik, Rozwój osadnictwa w okolicach Łodzi, Łódź 1948 (Acta Geographica Lodziensia, 2); tenże, Województwo ze stolicą bez antenatów. Geografia historyczna województwa tódzkiego, Łódź 1971; M. Koter, Rola wiejskich elementów morfologicznych w procesie ksztattowania układu przestrzennego todzi, w: Zagadnienia geografii historycznej osadnictwa w Polsce. Materiaty konferencyjne, red. M. Koter, J. Tkocz, ToruńŁódź 1994, s. 63-88; J. Warężak, Osadnictwo kasztelanii towickiej 1136-1847, Łódź 1952; S. Wojtkowiak, Badania nad ksztattami osiedli wiejskich ziemi tęczyckiej w średniowieczu, rozprawa doktorska, mps w Bibliotece Uniwersytetu Łódzkiego, Łódź 1962.

${ }^{6}$ M. Koter, Fizjonomia, morfologia i morfogeneza miasta. Przegląd rozwoju oraz próba uściślenia pojęć, „Zeszyty Naukowe Uniwersytetu Łódzkiego. Seria 2, Nauki Matematyczno-Przyrodnicze”, 55, 1974, s. 3-16; tenże, Od fizjonomii do morfogenezy i morfologii porównawczej. Podstawowe zagadnienia teoretyczne morfologii miast, w: Zagadnienia geografii historycznej, s. 23-32.
} 
jako wyniku oddziaływania czynników fizjograficznych, politycznych i transformacji systemów społeczno-gospodarczych na przestrzeni dziejów.

Badany obszar, utożsamiany na potrzeby pracy ze współczesnym regionem administracyjnym ze stolicą w Łodzi, ukształtowany został na pograniczu Wielkopolski (dawne województwa łęczyckie i sieradzkie wraz z częścią ziemi wieluńskiej), Mazowsza (zachodni skraj dawnego województwa rawskiego) oraz Małopolski (północno-zachodnie peryferia przedrozbiorowego województwa sandomierskiego) ${ }^{7}$. Przejściowy w sensie geograficzno-historycznym charakter analizowanego obszaru wpłynął na specyficzny, dośrodkowy rozwój osadnictwa wiejskiego, a co za tym idzie, odzwierciedlił się w sferze układów ruralistycznych.

Analizie podlegały wsie powstające w różnych okresach historycznych - od wczesnego średniowiecza do uwłaszczenia chłopów w 1864 r. Badano osady, które w sensie formalnoprawnym od powstania zachowały trwale wiejski charakter, jak również te, które na pewnym etapie rozwoju uległy inkorporacji do pobliskich miast, lecz do dziś zachowały czytelne relikty pierwotnego rozplanowania. W związku z przyjętą periodyzacją morfogenetyczną badania podstawowe objęły wsie: $\mathrm{z}$ metryką wczesnośredniowieczną oraz te, które nie przeszły regulacji średniowiecznej; regularne z okresu średniowiecza, które przeszły lokację na prawie niemieckim; z okresu rozwoju gospodarki folwarczno-pańszczyźnianej; nowożytne, związane $\mathrm{z}$ osadnictwem olęderskim i kolonizacją fryderycjańską oraz ukształtowane w wyniku procesów reorganizacji przestrzennej w XIX w. (komasacyjno-separacyjnych i parcelacyjnych).

\footnotetext{
7 J. Chańko, J. Szymczak, Dzieje polityczne i struktury terytorialno-administracyjne, w: Zarys monografii województwa tódzkiego, red. S. Liszewski, Łódź 2001, s. 135-153; R. Rosin, Rozwój terytorialno-polityczny dawnych ziemwojewództwa łódzkiego, „Prace i Materiały Muzeum Archeologicznego w Łodzi”, 22, 1975, s. 411-433.

${ }^{8}$ T. Figlus, Morfogeneza wsi na obszarze Polski Środkowej, rozprawa doktorska, mps w Bibliotece Uniwersytetu tódzkiego, Łódź 2013.

${ }^{9}$ Tenże, Wybrane aspekty zastosowania wielkoskalowych źródet kartograficznych w badaniach morfogenetycznych wsi, w: Dawne mapy jako źródła historyczne, red. B. Konopska i in., Warszawa 2012 (Biblioteka Polskiego Przeglądu Kartograficznego, 3), s. 91-103.
}

Opracowanie artykułu poprzedziły kilkuletnie badania ukierunkowane na analizę zróżnicowania morfogenetycznego wsi w środkowej Polsce. Ich efektem było powstanie studium na temat procesu kształtowania form rozplanowania na tle rozwoju osadnictwa oraz zróżnicowania subregionalnego układów ruralistycznych, przy uwzględnieniu identyfikacji cennych pod względem kompozycyjnym reliktów we współczesnym krajobrazie kulturowym badanego obsza$\mathrm{ru}^{8}$. W warunkach niedostatecznie zachowanej bazy źródłowej w postaci archiwalnych planów poszczególnych jednostek osadniczych w stosunku do ich dużej liczebności甲 oraz dostrzeżonej na etapie studiów diagnostycznych powtarzalności struktur przestrzennych o podobnym pochodzeniu konieczne stało się dokonanie selekcji i generalizacji, powszechnie stosowanej $\mathrm{w}$ dotychczasowych w badaniach morfogenetycznych wsi w Polsce ${ }^{10}$. W ramach przyjętej periodyzacji wydzielono podzbiór wsi reprezentatywnych dla ogółu analizowanych jednostek osadniczych na podstawie cech diagnostycznych, pozwalających odzwierciedlić zróżnicowanie morfogenetyczne całej zbiorowości. W procedurze doboru przyjęto dwie podstawowe grupy kryteriów selekcyjnych. Pierwsza miała charakter obiektywny i obejmowała ograniczenia zewnętrzne, uwarunkowane dostępnością i czytelnością materiałów kartograficznych. Druga opierała się na determinantach genetyczno-morfologicznych. Uwzględniono w tym zakresie czynnik równomiernego rozkładu przestrzennego wsi, ich różnej genezy, form zabudowy i układu polnego, rodzaju własności, specyficznego położenia topograficznego itd. W odniesieniu do omawianego obszaru szczegółowej analizie poddano podzbiór liczący 124 wsie. Po przeprowadzeniu wnikliwych badań morfologiczno-porównawczych możliwe było dokonanie na podstawie wyselekcjonowanego podzbioru generalizacji zwieńczonej procedurą typologiczną oraz wizualizacją kartograficzną

\footnotetext{
${ }^{10}$ Por. H. Szulc, Problem generalizacji układów przestrzennych wsi, „Kwartalnik Historii Kultury Materialnej”, 27 (4), 1969, s. 721-733; J. Tkocz, Uwagi metodyczne o generalizacji układów przestrzennych jednostek osadniczych w badaniach geograficzno-historycznych, w: Niektóre teoretyczne problemy rolniczego osadnictwa, red. J. Tkocz, Opole 1971.
} 
Niniejszy artykuł wykazuje walor syntetyzujący w kontekście przeprowadzonych uprzednio badań podstawowych i opiera się na wykonanej analizie porównawczej. Celem opracowania było zaprezentowanie i spopularyzowanie jednego z efektów końcowych zrealizowanego projektu naukowego $\mathrm{w}$ postaci typologii morfogenetycznej wsi na obszarze środkowej Polski. Wyszczególniono tu 22 jednostki osadnicze w aspekcie ich morfogenezy. Analizowane wsie, co wynika z dotychczasowych rozważań wstępnych, nie stanowiły jednak bazy do wykonania typologii, lecz są tylko skonkretyzowanymi reprezentantami wydzielonych typów na podstawie znacznie większej liczby przypadków. Ukazane w artykule typy morfogenetyczne wsi jako rezultat generalizacji badań podstawowych zgodnie z intencją autora mogą stanowić przede wszystkim podstawę do dalszych uszczegółowień na poziomie mikroskalowym lub bazę odniesienia do międzyregionalnych badań o charakterze porównawczym.

$\mathrm{Na}$ potrzeby dokonanej tu analizy wsi reprezentujących poszczególne typy morfogenetyczne korzystano $\mathrm{z}$ dostępnych wydawnictw źródłowych, w tym zbiorów dokumentów i materiałów statystyczno-opisowych w postaci wybranych kodeksów dyplomatycznych (głównie Wielkopolski i Mazowsza), ksiąg uposażeń i wizytacji kościelnych (Liber beneficiorum, wizytacji dóbr archidiecezji gnieźnieńskiej oraz biskupstwa włocławskiego), wybiórczo rejestrów

\footnotetext{
${ }^{11}$ Szerzej: T. Figlus, Morfogeneza, s. 17-24. Wykorzystane materiały źródłowe dotyczące wyselekcjonowanych na potrzeby artykułu jednostek osadniczych zostały przytoczone w dalszej części artykułu.

${ }^{12}$ S. Zajączkowski, S.M. Zajączkowski, Materiaty do stownika geograficzno-historycznego dawnych ziem tęczyckiej i sieradzkiej do 1400 roku, cz. 1-2, Łódź 1966-1970; R. Rosin, Stownik historyczno-geograficzny ziemiwieluńskiejwśredniowieczu,Warszawa 1963; Stownikgeograficzny Królestwa Polskiego i innych krajów słowiańskich [dalej: SGKP], t. 1-16, wyd. B. Chlebowski, F. Sulimierski, W. Walewski, Warszawa 1880-1902; J. Warężak, Stownik historyczno-geograficzny Księstwa towickiego, cz. 2, z. 1, Wrocław-Warszawa-Kraków 1961; tamże, z. 2, Łódź 1967; Mazowsze w drugiej połowie XVI w., cz. 1-2, red. W. Pałucki, oprac. A. Dunin-Wąsowiczowa i in., Warszawa 1973 (Atlas historyczny Polski. Mapy szczegótowe XVI wieku, 7); Województwo sandomierskie w drugiej pofowie XVI w., cz. 1-2, red. W. Pałucki, oprac. K. Chłapowski i in., Warszawa 1993 (Atlas historyczny Polski. Mapy szczegótowe XVI wieku, 2); Województwo sieradzkie i województwo tęczyckie w drugiej połowie XVI w. cz. 1-2, red. H. Rutkowski, oprac. K. Chłapowski i in., Warszawa 1998 (Atlas historyczny Polski. Mapy szczegótowe XVI wieku, 5).
}

poborowych z XVI w. (zestawionych przez Adolfa Pawińskiego) i wydanych drukiem lustracji królewszczyzn ${ }^{11}$. Pozyskiwano z nich informacje na temat pierwszej wzmianki, daty ewentualnej lokacji na prawie niemieckim, formy własności, informacji o folwarku i jego areale oraz o wielkości zabudowy i liczebności mieszkańców. Część danych ilościowych na temat poszczególnych wsi zestawiono pod koniec pracy (tab. 1). Korzystano również ze słowników geograficzno-historycznych i opracowań atlasowych ${ }^{12}$. Niezależnie od tego podjęto kwerendę materiałów kartograficznych, głównie rękopiśmiennych planów wsi i historycznych map topograficznych z Archiwum Głównego Akt Dawnych w Warszawie (dalej: AGAD) oraz Archiwum Państwowego w Łodzi (dalej: APŁ).

W pracy stosowano zróżnicowany zestaw metod morfologiczno-porównawczych, spośród których na szczególną uwagę zasługują retrogresywne, w tym tzw. metoda zapisu wstecznego ${ }^{13}$. Skorzystano również z metod genetyczno-metrologicznych. W wielu przypadkach dzięki znajomości chronologii systemu miar i idei planistycznych możliwe było określenie generalnych zasad rozplanowania wsi regularnych (np. lokowanych na prawie niemieckim) oraz ich odróżnienie od układów rozwijających się ewolucyjnie, w wyniku żywiołowej akcji osadniczej ${ }^{14 .}$. W stosunku do wsi nowszego pochodzenia przydatne okazały się również metody progresywne. Przy ustaleniu genezy osad oprócz zasady pierwszego zapisu positkowano się metodami toponomastycznymi i archeologicznymi. Bardzo ważnym etapem postępowania badawczego była ponadto lustracja terenowa, która pozwoliła na uchwycenie reliktów dawnych form osadnictwa wiejskiego.

\footnotetext{
${ }^{13} \mathrm{~A}$. Krenzlin, Dorf, Feld und Wirtschaft im Gebiet der großen Täler und Platten östlich der Elbe, Remagen 1952; G. Labuda, Uwagio przedmiocie i metodzie geografii historycznej, „Przegląd Geograficzny”, 25 (1), 1953, s. 5-56.

${ }^{14} \mathrm{D}$. Hannerberg, Solskifte and Older Methods of Partitioning Arable Land in Central Sweeden during the Middle Ages, w: Géographie et histoire agraires, Actes du colloque international organisé par la Faculté de Lettres de I'Université de Nancy, ed. X. De Planhol, [b.m.w.] 1959, s. 245-259 (Annales de l'Est, Mémoire, 21); S. Golachowski, B. Kostrubiec, A. Zagożdżon, Metody badań geograficzno-osadniczych, Warszawa. 1974; J. Sheppard, Metrological Analysis of Regular Village Plans in Yorkshire, „The Agricultural History Review”, 22 (2), 1974, s. 118-135.
} 


\section{Nieregularne wsie o metryce średniowiecznej}

Pierwszy z rozpatrywanych okresów morfogenetycznych, dla którego przeprowadzono badania podstawowe $\mathrm{w}$ zakresie układów ruralistycznych, obejmuje wsie powstałe we wczesnym średniowieczu oraz pozostałe, które nie przeszły regulacji w związku z lokacją na prawie niemieckim. Za ich wczesną metryką historyczną przemawiają zazwyczaj przesłanki archeologiczne (bliskość grodzisk, luźne znaleziska), zapiski w źródłach pisanych, specyficzna toponimia (np. osady służebne) ${ }^{15}$ lub pozostałości budownictwa typowego dla okresu przedlokacyjnego (architektura romańska) ${ }^{16}$. Były to wsie, które powstawały samorodnie i rozwijały się $\mathrm{w}$ sposób ewolucyjny. Szczególny wpływ na proces kształtowania się wiejskiej sieci osadniczej wywarly w tym czasie czynniki przyrodnicze (rozwój osadnictwa w strefach dolinnych), stosunki społeczne (rozpad wspólnoty pierwotnej i proces feudalizacji), gospodarcze (zanik gospodarki żarowo-odłogowej i upowszechnienie się stałej gospodarki ornej) i wreszcie polityczne oraz prawno-ustrojowe (rozwój systemu zespołów grodowych oraz kasztelanii) ${ }^{17}$.

W ramach przeprowadzonych badań udało się zidentyfikować typowe dla omawianego okresu morfogenetycznego formy siedlisk i rozłogów wiejskich. W kontekście badań archeologicznych za pierwotną formę rozplanowania można uznać wieś jednodworczą, która z czasem ulegała rozbudowie i dała początek skoncentrowanym osiedlom wielodworczym. $\mathrm{W}$ analizowanych na badanym obszarze siedliskach dominowały układy liniowe $\mathrm{w}$ postaci małych wsi drogowych, obustronnie lub jedno-

${ }^{15}$ Zob. I. Nobis, Stużebne nazwy miejscowe w Polsce piastowskiej, Kraków 2013.

${ }^{16} \mathrm{~J}$. Kamińska, Grody wczesnośredniowieczne Polski środkowej na tle osadnictwa, Łódź 1953; A. Chmielowska, Badania nad wczesnośredniowiecznym osadnictwem grodowym i jego wiejskim zapleczem na obszarze Polski środkowej, „Acta Universitatis Lodziensis. Seria 1”, 36, 1979, s. 35-51; J. Sikora, Ziemie centralnej Polski we wczesnym średniowieczu. Studium archeologiczno osadnicze, Łódź 2009; Z. Podwińska, Zmiany form osadnictwa wiejskiego na ziemiach polskich we wcześniejszym średniowieczu: źreb, wieś, opole, Warszawa 1971.

${ }^{17}$ Taż, Gospodarstwo wiejskie w okresie wczesnofeudalnym (V w.-początek XII wieku), w: Zarys historii gospodarstwa wiejskiego w Polsce, t. 1, red. J. Leskiewiczowa, Warszawa 1964, s. 183-264. stronnie zabudowanych wzdłuż krzywoliniowej drogi, np. Grzmiąca w gm. Brzeziny (ryc. 1) ${ }^{18}$. Oddzielną grupę stanowity małe wsie placowe. Na szczególną uwagę zasługują w tym przypadku pojedynczo występujące okolnice, w tym niepełne, np. Borszewice w gm. Łask, dawna wieś arcybiskupów gnieźnieńnkich ${ }^{19}$. Zwarta zabudowa koncentrowała się tu wokół okraggego placu z kościołem pośrodku, a działki siedliskowe tworzyły wachlarzowaty układ radialny (ryc. 2). Powszechnie występującą grupę siedlisk stanowity małe, nieregularne owalnice, czego egzemplifikację stanowić może Zdziechów w gm. Dalików ${ }^{20}$. Na siedlisko składały się tu nieregularnie rozmieszczone zagrody tworzące łukowatą strukturę wokół nieforemnego, zbliżonego do owalu placu (ryc. 3). Niezwykle istotne znaczenie we wsiach wczesnofeudalnych miały również układy wielodrogowe. Najprostszą ich postać stanowiły na badanym obszarze formy rozdrożne o charakterze widlicowym. Dużo bardziej skomplikowany układ przestrzenny reprezentowały wielodrożnice, cechujące się chaotyczną zabudową i zawiłym układem komunikacyjnym, czego doskonałym przykładem jest dawna osada kasztelańska Spycimierz, wzmiankowana już na pocz. XII w. w kontekście konfliktu między książętami piastowskimi Bolesławem Krzywoustym i jego bratem Zbigniewem (ryc. 4) ${ }^{21}$. Wszystkie z wymienionych typów siedlisk miały charakter inicjalny, gdyż pojawiały się w wyniku żywiołowej akcji osadniczej na obszarze wcześniej niezagospodarowanym. Były to zazwyczaj formy pierwotne (wcześniej nieznane), silnie dostosowane do lokalnych warunków fizjograficznych. Do ewolucyjnych form zaliczyć można jedynie

\footnotetext{
${ }^{18}$ Wieś notowana w źródłach od 1389 r. Księgi sądowe tęczyckie od 1385 do 141 [dalej: KSŁ], cz. 1, w: Teki A. Pawińskiego, t. 3, Warszawa 1897, s. $118, \mathrm{nr} 1250$.

${ }^{19}$ Wieś wzmiankowana po raz pierwszy w 1357 r. w dokumencie potwierdzającym uposażenie arcybiskupów gnieźnieńskich. Kodeks dyplomatyczny Wielkopolski [dalej: KDW], t. 3, wyd. I. Zakrzewski, Poznań 1879, nr 1354.

${ }^{20}$ Wieś arcybiskupia odnotowana po raz pierwszy w wymienionym uprzednio dokumencie z $1357 \mathrm{r}$.

${ }^{21}$ Galli Anonymi cronica et gesta ducum sive principium Polonorum, wyd. K. Maleczyński, Kraków 1952, s. 108 (Monumenta Poloniae Historica. Series Nova, 2). Zob. T. Figlus, Rozwój układu ruralistycznego Spycimierza na tle dziejów osadnictwa w świetle badań geograficzno-historycznych i archeologicznych, „Biuletyn Uniejowski”, 4, 2015, s. 73-94.
} 
wielodrożnice, kształtowane długotrwale w wyniku stopniowego rozrostu wsi drogowych lub placowych bądź w rezultacie łączenia się niewielkich przysiółków. Znamienne, że wspólną cechą siedlisk wsi środkowopolskich były w omawianym okresie małe rozmiary oraz nieregular- ność układu przestrzennego. Przejawiała się ona w asymetrycznym położeniu siedliska w stosunku do granic wsi, brakiem wyraźnych granic zewnętrznych niwy domowej oraz nierówną wielkością, różnym kształtem i przebiegiem działek siedliskowych.

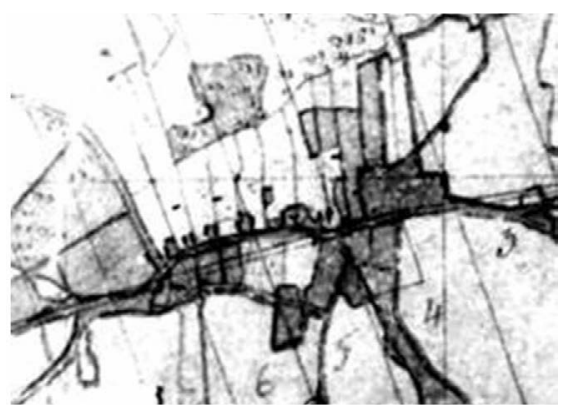

Ryc. 1. Grzmiąca. Plan z 1850 r. Źródto: APt, Zb. kart., sygn. 156

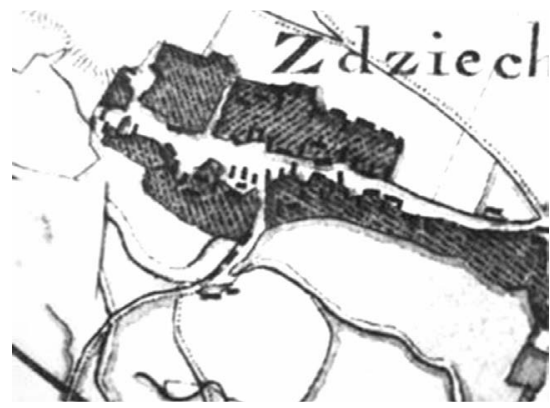

Ryc. 3. Zdziechów. Plan z 1826 r. Żródto: APt, Zb. kart., sygn. 104

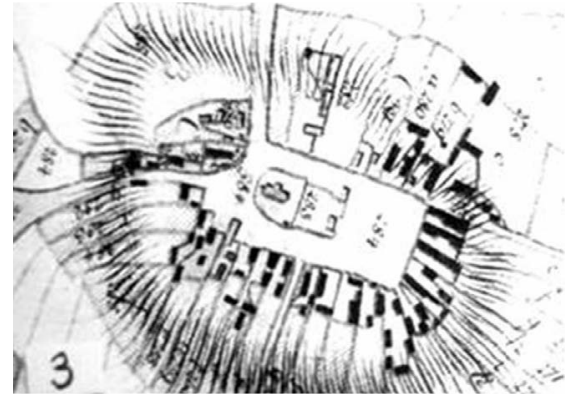

Ryc. 2. Borszewice. Plan z 1807 r.

Źródto: AGAD, Zb. kart., sygn. 261-7

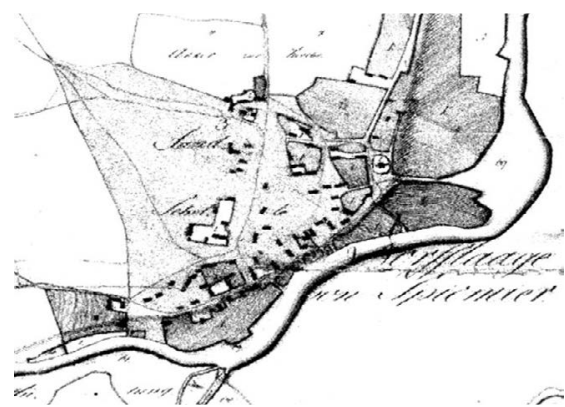

Ryc. 4. Spycimierz. Plan z 1804 r.

Żródto: AGAD, Zb. kart., sygn. 344-4

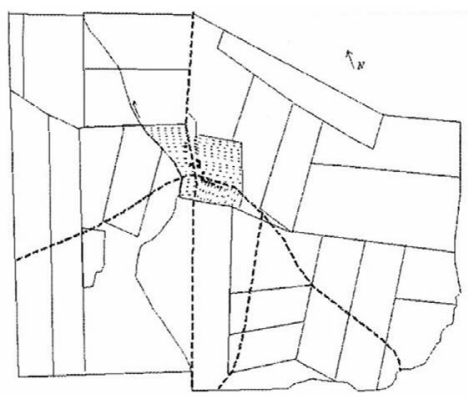

Ryc. 5. Bychlew. Odrys planu z 1796 r. Żródto: AGAD, Zb. kart., sygn. 293-12 
Omówionym typom siedlisk wsi odpowiadały określone formy rozłogów, które wykształciły się w warunkach żarowej lub dwupolowej gospodarki rolnej oraz stopniowej feudalizacji stosunków społeczno-własnościowych. W kontekście badań archeologicznych udało się stwierdzić, że pierwotnym siedliskom jednodworczym towarzyszył układ poloniarski w postaci nieregularnych działek otaczających zagrodę. Najczęściej spotykaną formą rozłogów, która współwystępowała z siedliskami wielodworczymi, był układ blokowy, cechujący się obecnością małych działek blokowych należących do poszczególnych właścicieli. Była to forma pierwotna, czytelna dzięki rekonstrukcji dokonanej z zastosowaniem metody sąsiedztwa Johanna Rippla ${ }^{22}$. Jego egzemplifikację może stanowić układ rozłogów wsi Bychlew w gm. Pabianice, „villa capitularis in iure Polonico locata"23. Wieś nigdy nie przeszła lokacji na prawie niemieckim i rozwijała się ewolucyjnie w oparciu o zwyczajowe prawo polskie. Wtórny wobec omawianej formy rozłogów był układ blokowo-pasmowy, powstały w wyniku późniejszych podziałów własnościowych (ryc. 5). Tworzyły go zespoły działek usytuowanych w blokach, co było rezultatem przystosowania do warunków gospodarski opartej na trójpolówce. Zidentyfikowano ponadto układy rozłogów składające się z wielu nieregularnych niw o niekompletnej powtarzalności własności oraz specyficznym rozrzucie działek. Oba przedstawione typy rozłogów mają charakter naśladowczy i są formami ewolucyjnymi.

\section{Wsie lokowane na prawie niemieckim, które przeszły regulację w okresie średniowiecza}

Drugi z wydzielonych okresów morfogenetycznych odnosi się do rozwoju osadnictwa

\footnotetext{
${ }^{22} \mathrm{~J}$. Rippel, Eine statistische Methode zur Untersuchung von Flur- und Ortsentwicklung, ,Geografiska Annaler”, 43 (1-2), 1961, s. 252-263.

${ }^{23}$ Joannis Dlugossii Senioris Canonici Cracoviensis Opera omnia, t. 9: Joannis Długosz Senioris Canonici Cracoviensis Liber beneficiorum dioecesis cracoviensis [dalej: DLB], t. 3, wyd. A. Przezdziecki, Kraków 1864, s. 276. Według Maksymiliana Barucha wieś wymieniona została po raz pierwszy w $1398 \mathrm{r}$. w akcie uposażenia kościoła w Pabianicach (na podstawie „wypisu z liber antiquus beneficiorum archidiecezji gnieźnieńskiej”). Zob. M. Baruch, Rzgów i wsie okoliczne: monografia historyczna dawnych dóbr kapituty krakowskiej w Sieradzkim i Łęczyckim, Warszawa 1903, s. 245.
}

opartego na recepcji prawa niemieckiego i towarzyszącej mu regulacji wsi do pocz. XVI w. Dochodziło wtedy do powstawania nowych wsi na surowym korzeniu lub kształtowania układów przestrzennych na skutek reorganizacji wsi o wcześniejszej metryce historycznej. $\mathrm{Na}$ rozwój wiejskiej sieci osadniczej w okresie pełnego i późnego średniowiecza przemożny wpływ wywarły czynniki prawno-ustrojowe (rozpowszechnienie prawa niemieckiego i oczynszowanie chłopów), gospodarczo-agrarne (rozwój regularnej formy trójpolówki) oraz społeczno-własnościowe (rozwój wielkiej własności ziemskiej, ze szczególnym uwzględnieniem znaczenia dóbr królewskich i kościelnych ${ }^{24}$. Wśród charakterystycznych dla tego okresu typów siedlisk w środkowej Polsce można wyróżnić kilka kategorii wsi o specyficznych cechach rozplanowania: zwarte, duże ulicówki oraz owalnice. Ulicówki, w odróżnieniu od znanych wcześniej wsi drogowych, stanowiły układy regularne, w których zwarta zabudowa koncentrowała się obustronnie $\mathrm{w}$ formie liniowej, wzdłuż wyprostowanej drogi lub niewielkiej rzeki. Egzemplifikacją tego układu może być Wola Mąkolska w gm. Głowno, nowo lokowana na prawie średzkim przed $1427 \mathrm{r}$. w dobrach arcybiskupów gnieźnieńskich (ryc. 6) ${ }^{25}$. Przy rozmierzaniu wsi lokowanych stosowano także model owalnicowy, o dość dużym spektrum odmian w zakresie rozplanowania. Różniły się one wielkością założenia oraz powierzchnią, kształtem i zagospodarowaniem nawsia. Pod względem wielkości niwy siedliskowej można tu wyróżnić zarówno układy małe, jak i duże. W zależności od pełnionych funkcji nawsie przybierało różny kształt - od małego owalu po wrzeciono o różnym stopniu wydłużenia. W zależności od sposobu użytkowania w jego obrębie usytuowane były staw i pastwisko (np.

\footnotetext{
${ }^{24}$ S. Zajączkowski, Studia nad osadnictwem dawnych ziem tęczyckiej i sieradzkiej w XII-XIV w. Uwagi i spostrzeżenia, „Studia z Dziejów Osadnictwa", 4, 1966, s. 2-85; S.M. Zajączkowski, O lokacjach wsi na prawie niemieckim $w$ Łęczyckiem i Sieradzkiem od końca XIV do początków XVI wieku, Łódź 1974; R. Rosin, Ziemia Wieluńska XII-XVI w. Studia z dziejów osadnictwa, Łódź 1961.

${ }_{25} \mathrm{~J}$. Korytkowski, Arcybiskupi gnieźnieńscy: prymasowie i metropolici polscy od roku 1000 aż do roku 1821, t. 2, Poznań 1888, s. 105.
} 
w subregionie piotrkowsko-opoczyńskim) lub zabudowa, w tym kościół (np. w subregionie sieradzko-wieluńskim) ${ }^{26 .}$ Dobrym przykładem takiego typu rozplanowania jest wieś Wiaderno w gm. Tomaszów Mazowiecki, wzmiankowana od 1363 r., kiedy to biskup kujawski Maciej z Gołańczy nadał Albertowi z Zakrzewa prawo do lokowania osady na prawie średzkim, określając przy tym uposażenie i obowiązki sołtysa oraz powinności osadników (ryc. 7$)^{27}$. We wsiach placowych stosowano również

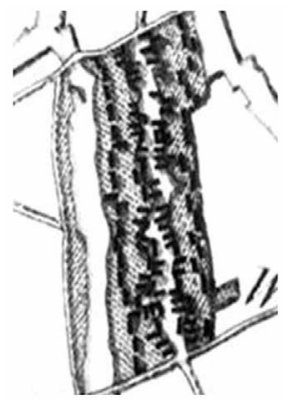

Ryc. 6. Wola Mąkolska, plan wsi z 1826 r. Źródto: APt, Zb. kart., sygn. 96

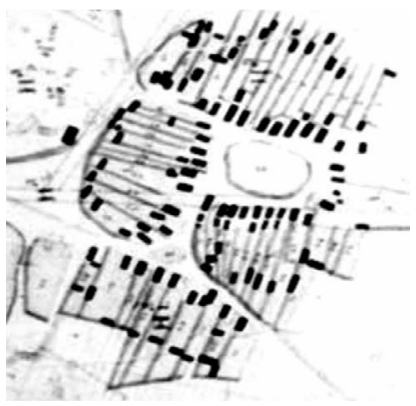

Ryc. 8. Biskupia Wola. Plan wsi z 1845 r. Źródto: AGAD, Zb. kart., sygn. 203-9 układ trójkątnoplacowy, jako uregulowaną formę dawnej widlicy, lub prostokątnoplacowy, którego unikalną odmianę stanowi zidentyfikowana na badanym obszarze wieś ryneczkowa z kwadratowym nawsiem. Przykładem może tu być Biskupia Wola w gm. Czarnocin (ryc. 8) ${ }^{28}$. Zdarzały się również formy złożone, np. zespolone i krzyżujące się ulicówki. Warto wspomnieć, że wszystkie omawiane do tej pory typy siedlisk miały genezę naśladowczą, gdyż opierały się na zmodyfikowanych wzorcach rozplanowa-

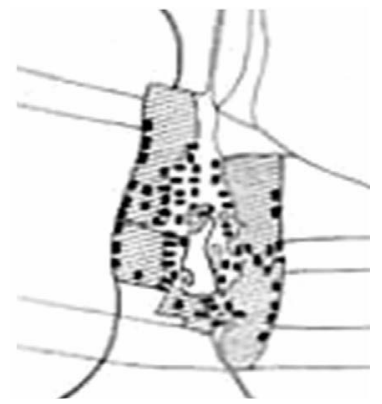

Ryc. 7. Wiaderno. Odrys planu z 1829 r. Źródto: APt, Zb. kart., sygn. 24

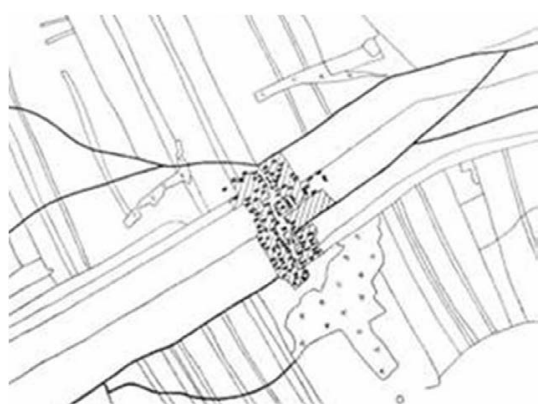

Ryc. 9. Czastary. Odrys planu z 1832 r.

Żródto: APt, Zb. kart., sygn. 114

\footnotetext{
${ }^{26}$ T. Figlus, Wybrane zagadnienia morfogenetyczne owalnic w Polsce Środkowej, w: Wspótczesne zagadnienia, problemy i wyzwania w badaniach geograficznych, t. 2, red. T. Wiskulski, M. Pilarski, Gdańsk 2013, s. 141-153.

${ }^{27}$ Dokumenty kujawskie i mazowieckie przeważnie z XIII wieku [dalej: DKMaz], wyd. B. Ulanowski, Kraków 1887, s. 257, nr 80 (Archiwum Komisji Historycznej, 4).

${ }^{28}$ Wieś notowana prawdopodobnie po raz pierwszy w księgach grodzkich piotrkowskich z 1413 r. S. Kozierowski, Badania nazw topograficznych
}

na obszarze dawnej wschodniej Wielkopolski, t. 2, Poznań 1928, s. 234. Człon nazewniczy wola stanowi zapewne świadectwo przywileju wolnizny, czyli okresowego zwolnienia z powinności feudalnych uzyskanego na etapie lokacji wsi, szczególnie in cruda radice. Zob. J. Matuszewski, Nazwy administracyjne osad lokowanych na prawie niemieckim, Łódź 1974, s. $42-65$. 
nia znanych już w okresie wczesnośredniowiecznym. Mogły przy tym wykazywać charakter inicjalny, w przypadku wsi zakładanych in cruda radice, lub transformacyjny, gdy chodzi o osady powstałe $\mathrm{w}$ wyniku przeobrażenia struktur wcześniejszego pochodzenia. Ulicówki i wsie placowe przerosłe w układy wielodrogowe miały natomiast charakter ewolucyjny. Typową cechą siedlisk w tym okresie morfogenetycznym była ich regularność, przejawiająca się w centralnym położeniu siedliska $\mathrm{w}$ stosunku do granic wsi oraz zaplanowanym układem drożnym. Niwa domowa miała kształt zbliżony do prostokąta lub równoległoboku, a jej granice zewnętrzne były zazwyczaj wyraźne, oddzielone od rozłogów miedzami lub drogami zagumnymi.

Najbardziej charakterystyczną formą rozłogów, towarzyszącą regularnym siedliskom wsi średniowiecznych, był układ niwowo-łanowy. Tworzyły go regularne kompleksy pól o identycznym przebiegu i sposobie użytkowania pasm własnościowych, pomierzonych zgodnie $\mathrm{z}$ łanowym modułem mierniczym. Ich podział ściśle korespondował z dominującą formą gospodarowania w postaci trójpolówki. Poszczególne pola dzielono również na mniejsze niwy. Poza głównym układem pozostawały ponadto tworzone ewolucyjnie przymiarki. W wyniku przeprowadzonych badań podstawowych udało się zidentyfikować różne typy położenia niw względem siebie. Stosowano układ prostopadłoniwowy, w którym niwa środkowa leżała na przedłużeniu działek zagrodowych, zaś pozostałe były w stosunku do niej prostopadłe. Przykładem może tu być rozplanowanie wsi Czastary (gm. loco), dla której zachowały się informacje źródłowe na temat sołectwa świadczącego

\footnotetext{
${ }^{29}$ Wieś odnotowana została po raz pierwszy w 1403 r., w kontekście wzmianki o Nicolao Sculdzie piszącym się z Czastar. AGAD, Metryka Koronna [dalej: MK], ks. 64, k. 120v. Z 1461 r. pochodzi natomiast ujęta w księgach grodzkich wieluńskich informacja 0 transakcji sprzedaży gruntów sołeckich. Zob. R. Rosin, Stownik, s. 71. Potwierdzenie istnienia sołectwa (5 tanów) uzyskujemy również w rejestrach poborowych z połowy XVI w. Polska XVI wieku pod względem geograficzno-statystycznym opisana przez Adolfa Pawińskiego, t. 2: Wielkopolska, Warszawa 1883, s. 298 (Żródła Dziejowe, t. 13).

${ }^{30}$ Wieś po raz pierwszy wymieniona w dokumencie z 1473 r. AGAD, MK, ks. 5, k. 31-32.
}

o zaistnieniu lokacji (ryc. 9) ${ }^{29}$. Można także zidentyfikować układ równoległoniwowy, który cechował się równoległym przebiegiem zagonów w odniesieniu do wszystkich niw, czego przykładem jest układ przestrzenny wsi Piaski w gm. Nieborów (ryc. 10) ${ }^{30}$. Osobliwy okazał się na badanym obszarze typ nizinny leśno-łanowego układu rozłogów. Egzemplifikację może tu stanowić wieś Lubowidza w gm. Dmosin ${ }^{31}$. Jej układ cechował się szeregowym usytuowaniem zagród wzdłuż osi doliny, którym towarzyszył pasmowy układ pól indywidualnych (ryc. 11). Omawiane formy rozłogów miały niewątpliwie charakter pierwotny, nieznany w poprzednim okresie morfogenetycznym.

\section{Układy ruralistyczne pochodzenia nowożytne- go (XVI-pocz. XIX w.)}

Trzeci z wyróżnionych okresów morfogenetycznych odnosi się do czasów nowożytnych. Obejmuje on rozwój stosunków folwarczno-pańszczyźnianych i związany $\mathrm{z}$ tym proces transformacji wsi o metryce średniowiecznej lub powstawania nowych punktów osadniczych według nieznanych wcześniej wzorców rozplanowania. Kluczem do poznania dziejów wsi i ich układów przestrzennych jest proces refeudalizacji stosunków społecznych i rozwój gospodarczy oparty na pracy odrobkowej chłopów ${ }^{32}$. Zmiany w tym zakresie przyniosło dopiero osadnictwo olęderskie i fryderycjańskie, które rozwijało się w warunkach czynszowych i miało na celu zagospodarowanie nieużytków, głównie w dawnych dobrach królewskich i kościelnych, rzadziej zaś w majątkach szlacheckich ${ }^{33}$.

Wśród siedlisk wiejskich wyraźnie dominowały w tym czasie wsie folwarczno-kmiece, jako

\footnotetext{
${ }^{31}$ Wieś wzmiankowana w materiale źródłowym od 1386 r. KSt, cz. 1, nr 108, s. 14.

${ }^{32}$ S.M. Zajączkowski, Początki folwarku w ziemiach tęczyckiej i sieradzkiej (do początków XVI w.), ,"Roczniki Dziejów Społeczno-Gospodarczych”, 31, 1970, s. 1-43; B. Baranowski, Gospodarstwo chłopskie i folwarczne we wschodniej Wielkopolsce w XVIII wieku, Warszawa 1958.

${ }^{33} \mathrm{~J}$. Goldberg, Osadnictwo olęderskie w dawnym województwie łęczyckim i sieradzkim, „Zeszyty Naukowe Uniwersytetu tódzkiego. Seria 1, Nauki Humanistyczno-Społeczne", 5, 1957, s. 67-110; K.P. Woźniak, Niemieckie osadnictwo wiejskie między Prosną a Pilicą i Wisłą od lat 70. XVIII wieku do 1866 r. Proces i jego interpretacje, Łódź 2013.
} 


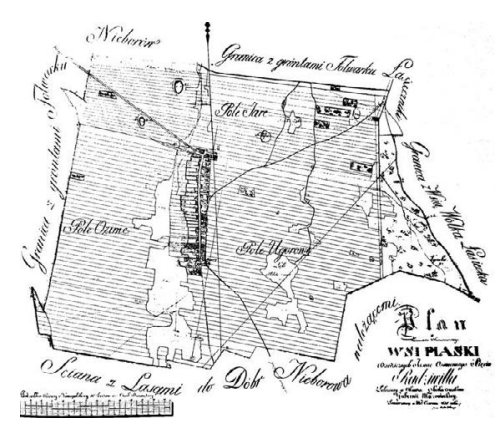

Ryc. 10. Piaski. Plan z 1839 r.

Żródto: AGAD, Zb. kart., sygn. 530-15

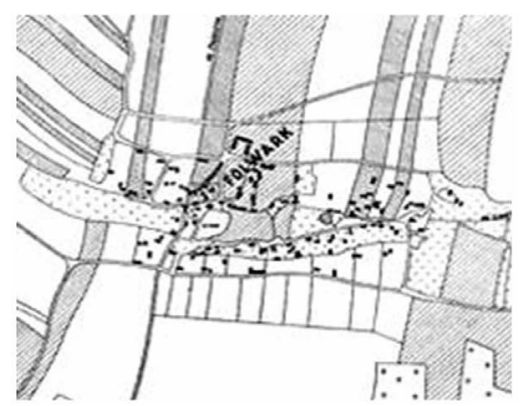

Ryc. 12. Makowiska. Odrys planu z 1794 r.

Źródto: APt, Zb. kart., sygn. 141a

forma wtórna o charakterze ewolucyjnym. Folwark sprzężony był w nich $\mathrm{z}$ zabudową kmiecą. Cechami różnicującymi omawiane układy była liczba folwarków oraz relacja przestrzenna zabudowy włościańskiej i folwarku. Można tu wyróżnić układy z jednym lub wieloma folwarkami (tzw. polnymi). Jeżeli chodzi o przestrzenne relacje folwarku i siedliska wiejskiego, udało się zidentyfikować jego położenie centralne lub na skraju siedliska, czego przykładem może być wieś Makowiska w gm. Pajęczno (ryc. 12) ${ }^{34}$. $\mathrm{Z}$ akt wizytacji dóbr arcybiskupich w XVI w. uzyskujemy informację na temat 3 łanów areału

\footnotetext{
${ }^{34}$ Wieś wzmiankowana po raz pierwszy 1357 r. (KDW, t. 3, nr 1354), lokowana w 1359 r. na prawie średzkim przez arcybiskupa Jarosława Bogorię Skotnickiego. Visitationes bonorum archiepiscopatus necnon capituli Gnesnensis saeculi XVI, wyd. B. Ulanowski, Kraków 1920, s. 369-370.

${ }^{35}$ „Ibidem est praedium bonum, quia trium mansorum, et insuper duo mansi kmethonales deserti iuncti sunt eisdem tribus mansis praedialibus". Tamże, s. 370.
}

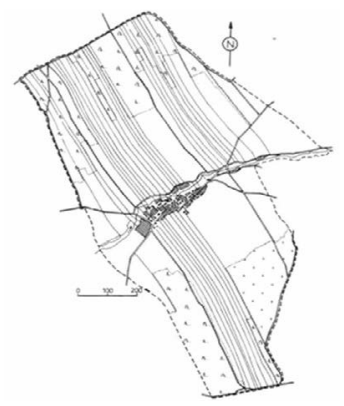

Ryc. 11. Lubowidza. Odrys planu z 1834 r. Żródto: AGAD, Zb. kart., sygn. 369-23

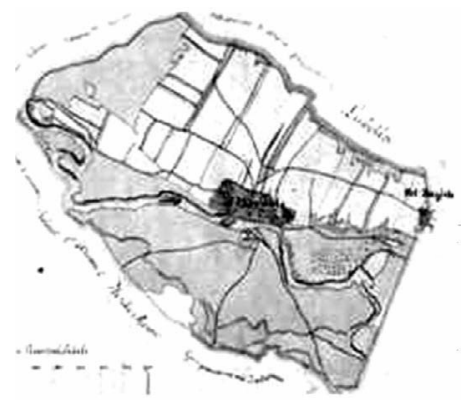

Ryc. 13. Brodnia. Plan z 1801 r.

Źródto: AGAD, Zb. kart., sygn. 279-26

ziemi folwarcznej, a ponadto 2 łanów użytkowanych przez folwark w wyniku zajęcia opuszczonych gruntów kmiecych (inkorporacji pustek osadniczych) ${ }^{35}$. Sporadycznie można zidentyfikować izolacyjne położenie folwarku w stosunku do siedliska kmiecego, czego doskonałym przykładem jest dawna wieś monarsza Brodnia w gm. Pęczniew ${ }^{36}$. W lustracji królewszczyzn z lat 1564-1565 1628-1632 odnajdujemy informację o 2 lanach gruntów folwarcznych, które powstały w wyniku wykupu sołectwa (ryc. 13) ${ }^{37}$.

Oprócz wsi folwarczno-kmiecych w środkowej Polsce powstawały autonomiczne osiedla

\footnotetext{
${ }^{36}$ Wieś znana z przekazów źródłowych od 1298 r. (Władysław Łokietek nadał kasztelanowi rudzkiemu Stoigniewowi wieś Niemojów w zamian za Brodnię). Zob. DKMaz, nr 16, s. 367

${ }^{37}$ Lustracja województw wielkopolskich i kujawskich 1564-1565, cz. 2, wyd. A. Tomczak, Bydgoszcz 1963, s. 4-5; Lustracja województw wielkopolskich i kujawskich 1628-1632, cz. 2: Województwo sieradzkie, wyd. Z. Guldon, Wrocław 1969, s. 71.
} 


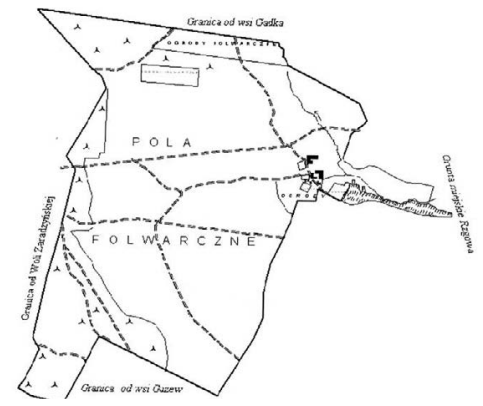

Ryc. 14. Gospodarz. Odrys planu z 1796 r.

Żródto: AGAD Zb. kart., sygn. 267-7

folwarczno-zagrodnicze, w których obok folwarku jako dominującego komponentu założenia przestrzennego funkcjonowała niewielka kolonia zagrodnicza, czego przykładem może być Gospodarz w gm. Rzgów. Osada folwarczna powstała tu $\mathrm{w}$ bezpośrednim sąsiedztwie miasta, którego potrzeby alimentacyjne miała zaspokajać (ryc. 14) ${ }^{38}$. W przeciwieństwie do wspomnianej wcześniej wsi folwarczno-kmiecej była to forma inicjalna, o charakterze pierwotnym. Oddzielną kwestią jest zróżnicowanie morfologiczne folwarków. Zdecydowaną większość z nich stanowią układy proste, obejmujące zabudowania gospodarcze wokół dziedzińca, sprzężone częstokroć z założeniem dworsko-parkowym. Zidentyfikowano również układy nie w pełni wykształcone, w tym tzw. folwarki polne, a na przeciwległym biegunie - układy złożone, z silnie rozwiniętą strukturą wewnętrzną i wyraźną dominacją przestrzenną komponentu rezydencjonalnego (np. w Nieborowie i Bratoszewicach).

Inną grupą siedlisk wiejskich w okresie nowożytnym były układy nieregularne, wykształcone w wyniku podziałów własnościowych wsi należących do szlachty cząstkowej bądź bezkmiecych, zamieszkiwanych przez szlachtę zagrodową. Podobną w sensie morfologicznym kategorię

\footnotetext{
${ }^{38}$ W lustracji dóbr kapituły krakowskiej z 1677 r. odnotowany zostat „folwark rzgowski przy mieście, zwany Gospodarz". Zob. M. Baruch, Rzgów, s. 91, 258. Wiadomo jednak, że już w 2. poł. XV w. w pobliżu podniesionego do rangi miasta Rzgowa funkcjonował folwark powstały na bazie dawnych gruntów wójtowskich: „[...] item decimam manipularem post agros praediales [...] in Rzgow, qui quondam erant scoltetiae". Zob. DLB, s. 275.
}

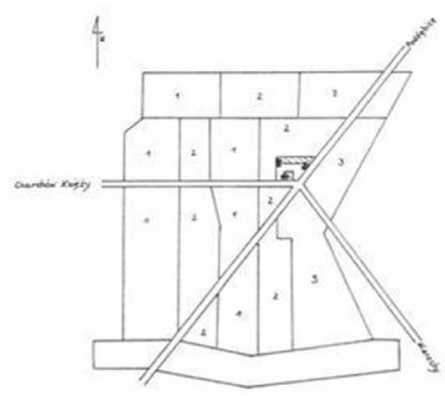

Ryc. 15. Budy Bratkowskie. Odrys planu z 1873 r.

Źródto: APt, Zb. kart., sygn. 2376

stanowią wsie protoprzemysłowe, w tym kuźnice, budy, smolarnie, huty oraz osady młyńskie i karczmarskie. Wszystkie wskazane wyżej typy genetyczne siedlisk mają charakter przysiółków i wsi samotniczych. Były to małe, nieregularne skupiska, powstające w wyniku spontanicznej akcji osadniczej. Tworzyły niewielkie zgrupowania zagród wzdłuż krótkiej, często ślepej drogi (przysiółki drogowe) lub koncentrowały się wokół niewielkiego placu (przysiółki placowe). Przykładem tego typu układu przestrzennego o genezie późnonowożytnej są Budy Bratkowskie w gm. Zadzim (ryc. 15).

Niezwykle istotną kategorię typologiczną wsi nowożytnych stanowią siedliska osad olęderskich i fryderycjańskich. Biorąc pod uwagę kryteria genetyczne, można tu wyróżnić dwie podstawowe grupy. Pierwsza obejmuje wsie przejęte i ponownie zasiedlone, czemu towarzyszyła reorganizacja układu przestrzennego (układy wtórne). Ilustruje to przykład Nowosolnej (daw. Neu-Sulzfeld), która obecnie znajduje się w granicach Łodzi (ryc. 18), a utworzona została z inicjatywy pruskiej administracji w $1801 \mathrm{r}$. na gruntach Wiączynia Polnego ${ }^{39}$. Druga kategoria zawiera natomiast wsie in cruda radice, np. Pawlikowice w gm. Pabianice (ryc. 16), utworzone w 1790 r. przez zarządcę dóbr kapituły krakowskiej Pawła Olechowskiego (układy inicjalne) ${ }^{40}$. Rozpatrując kryteria morfologiczne, można wy-

\footnotetext{
${ }^{39}$ 0. Heike, 150 Jahre Schwabensiedlungen in Polen 1795-1945, Leverkusen 1979, s. 61.

${ }^{40}$ E.0. Kossmann, Deutschrechtliche Siedlung in Polen, dargestellt am Lodzer raum, Posen-Leipzig 1939, s. 153-155.
} 
różnić układy swoiste, w formie rzędówek bagiennych (ryc. 16), z jedną lub dwiema osiami siedliskowymi w różnych konfiguracjach przestrzennych (równoległych, ukośnych, prostopadłych), z jednostronną lub obustronną zabudową, bądź układy wsi rozproszonych pierwotnie, czego przykładem jest Leśnik-Olendry w gm. Poddębice (ryc. 17), założony prawdopodobnie w $1796 \mathrm{r}^{41}$ W wyniku badań podstawowych wyróżniono również struktury mieszane (hybrydy morfologiczne), łączące obie wskazane formy typowe, z wyraźną dominacją jednej z nich. Zdecydowanie rzadziej tworzono natomiast układy nieswoiste $\mathrm{w}$ postaci zwartej, stanowiące kontynuację wcześniejszego modelu rozplanowania opartego na trójpolówce. Wśród wsi fryderycjańskich zidentyfikowano także układy o oryginalnej, zgeometryzowanej formie (ryc. 18), czego przykładem może być układ promienisto-koncentryczny czy też z siedliskiem prostokątnym.

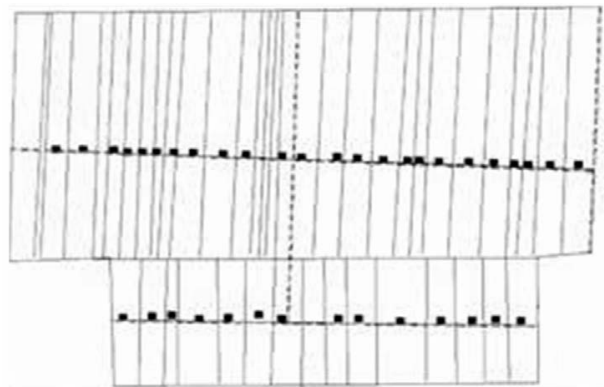

Ryc. 16. Pawlikowice. Odrys planu z 1795 r.

Żródto: AGAD, Zb. kart., sygn. 293-12

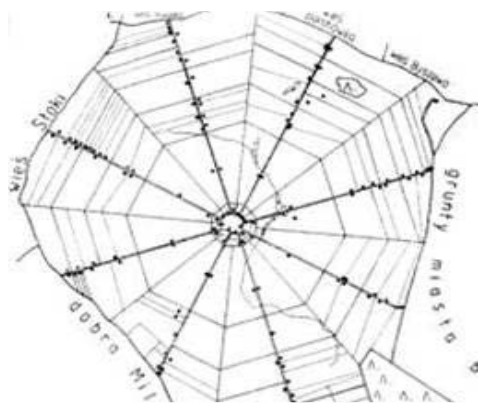

Ryc. 18. Nowosolna. Odrys planu z $1803 \mathrm{r}$.

Źródto: AGAD, Zb. kart., sygn. 267-15
Nie mniej istotną kwestią analizowaną na etapie badań podstawowych było w kontekście omawianego okresu morfogenetycznego zróżnicowanie typologiczne rozłogów. Dla siedlisk wsi folwarczno-kmiecych charakterystyczną formą okazały się układy folwarczno-niwowe. Cechowały się one przemieszaniem nadziałów pasmowych, należących do kmieci oraz własności folwarcznej w poszczególnych niwach, zgodnie $\mathrm{z}$ dominującą formą gospodarowania w postaci rotacyjnego systemu zmianowania (ryc. 12). Warto podkreślić, że w zdecydowanej większości zbadanych wsi była to forma wtórna, o charakterze ewolucyjnym. W pojedynczych wsiach z tego okresu odnotowano jednak zjawisko częściowej separacji pierwotnej rozłogów, polegającej na przemieszaniu nadziałów pasmowych włościan oraz należących do folwarku większych kompleksów polnych, które wykazywały cechy komasacyjne. W omawianym okresie

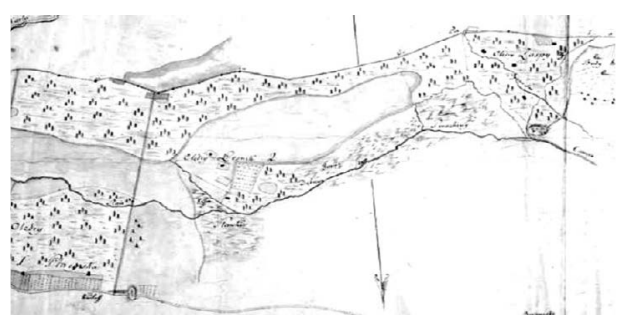

Ryc. 17. Leśnik Olendry. Plan z 1802 r.

Żródto: AGAD, Zb. kart., sygn. 381-10
${ }^{41}$ K.P. Woźniak, Niemieckie osadnictwo, s. 41; E.0. Kossmann, Die Deutschen in Polen seit der Reformation. Historisch-geographische Skizzen: Siedlung, Sozialstruktur, Wirtschaft, Marburg-Lahn 1978, s. 414. 
powstawały także osiedla folwarczne jako autonomiczne punkty osadnicze. Wiązały się z nimi układy folwarczno-wielkoblokowe jako formy o charakterze pierwotnym (ryc. 14). We wsiach tego typu praktycznie całość rozłogów stanowiła własność folwarku w formie dużych bloków, którym mogły towarzyszyć niewielkie nadziały zagrodnicze $^{42}$.

Najbardziej charakterystyczną formą rozłogów dla niewielkich przysiółków nowożytnych o zróżnicowanej genezie były układy blokowe, zazwyczaj nieregularne, wykazujące charakter naśladowczy (ryc. 15). Z czasem, w wyniku podziałów majątkowych ulegały one ewolucyjnemu przekształceniu w układy blokowo-pasmowe. W pojedynczych przysiółkach placowych udało się też zidentyfikować obecność unikalnego, radialnego układu rozłogów.

W większości wsi olęderskich i fryderycjańskich, ze względu na powszechność zastosowania siedliska w postaci rzędówki bagiennej, dominującą formą rozłogów były układy pasmowe, ze szczególnym uwzględnieniem nadziałów szerokopasmowych, indywidualnie użytkowanych przez poszczególnych właścicieli (ryc. 16). W przypadku osad rozproszonych można dostrzec obecność blokowego układu pól (ryc. 17) ${ }^{43}$. Mamy tu również do czynienia ze współwystępowaniem układu blokowego oraz nadziałów pasmowych, co w konsekwencji tworzy mniej typowy układ mieszany. W pojedynczych wsiach olęderskich, co sygnalizowano, stwierdzono ponadto istnienie regresywnego z punktu widzenia metod gospodarowania dawnego układu niwowego. W kilku przypadkach

\footnotetext{
${ }^{42}$ Szerzej zob. T. Figlus, Układy przestrzenne wsi folwarcznych w Polsce. Typy morfogenetyczne i ochrona dziedzictwa ruralistycznego, w: Rozwój zrównoważony regionów Polski, red. W. Wysota i in., Toruń 2011, s. $269-278$.

${ }^{43}$ Zob. W. Rusiński, Osady tzw. "Olędrów” w dawnym woj. poznańskim, Poznań-Kraków 1947; J. Burszta, Od osady, s. 108-117.

${ }^{44}$ Por. C. Ohryzko-Włodarska, Przemiany na wsi Królestwa Polskiego w latach 1846-1870. Na przykładzie powiatu brzezińskiego, Warszawa 1972; J. Kukulski, Przemiany na wsi powiatu piotrkowskiego w latach 1793 1918. Studia i materiały, Piotrków Trybunalski 2005; J. Śmiałowski, Zmiana $w$ nadziałach chtopów $w$ dobrach prywatnych powiatu sieradzkiego w pierwszej połowie XIX w., „Rocznik Łódzki”, 6, 1960, s. 145-172; F. Bortkiewicz, Nadziaty i powinności chłopów pańszczyźnianych w dobrach prywatnych Królestwa Polskiego, Warszawa 1958; B. Chomać,
}

wsi, szczególnie fryderycjańskich, udało się także zidentyfikować bardziej skomplikowane formy organizacji przestrzennej rozłogów z elementami układu radialnego (ryc. 18).

\section{Wsie poregulacyjne i poparcelacyjne z XIX w.}

Kolejny okres morfogenetyczny, wyszczególniony w zakresie rozwoju form osadnictwa wiejskiego na obszarze środkowej Polski, odnosi się do wielkich reform agrarnych zainicjowanych już pod koniec XVIII w. i kontynuowanych $\mathrm{z}$ różną intensywnością oraz efektywnością w XIX w., zarówno przed uwłaszczeniem chłopów, jak i po nim. Odnotowano wtedy zachodzące spontaniczne, na zasadach dobrowolności, jak i prowadzone odgórnie akcje komasacyjno-separacyjne rozłogów, procesy regulacyjne siedlisk oraz parcelacji majątków dworskich, mające na celu częściową lub całkowitą reorganizację przestrzenną wsi ${ }^{44}$. W tym kontekście stwierdzono istotne zróżnicowanie stopnia transformacji morfologicznej w zależności od okresu prowadzonych działań, typu własności ziemskiej oraz specyfiki społeczno-agrarnej wsi.

Omawiany okres morfogenetyczny obfitował w powstawanie typów siedlisk i rozłogów wiejskich w formie wtórnej, wykazującej charakter transformacyjny. Dochodziło bowiem w tym czasie do całkowitej przebudowy układu ruralistycznego, ukierunkowanej na powstawanie zupełnie nowych typów rozplanowania, w niewielkim stopniu nawiąujących do form inicjalnych. W związku z procesami komasacyjno-separacyjnymi powstawały układy przestrzenne siedlisk w formie dwuczłonowej, skła-

\footnotetext{
Struktura agrarna Królestwa Polskiego na przełomie XIX i XX wieku, Warszawa 1970; K. Groniowski, Kwestia agrarna w Królestwie Polskim 18711914, Warszawa 1966; Z. Stankiewicz, Zasady uwłaszczenia chłopów w Królestwie Polskim, w: Studia i materiaty do dziejów Łodzi i okręgu tódzkiego. Uwłaszczenie chłopów i mieszczan rolników, red. H. Brodowska, Łódź 1966, s. 23-82. Zob. też: D. Kowalik-Bodzak, Wpływ podziału spadkowego, komasacji i parcelacji na zmianę układów przestrzennych wsi w powiecie puławskim od połowy XIX w. Warszawa 1964, s. 97-152 (Dokumentacja Geograficzna, 4); A. Prochownik, Przemiany struktury osadniczo-agrarnej wsi powiatu proszowickiego od połowy XIX wieku do 1960 r. (na wybranych pokładach), Warszawa 1965 (Dokumentacja Geograficzna, 6); B. Szurowa, Przemiany osadnictwa wiejskiego na Kielecczyźnie w dobie przeduwłaszczeniowej. Zmiany układu przestrzennego wsi, Kielce 1995.
} 
dające się z rzędówki poregulacyjnej, sprzężonej z osiedlem folwarczno-zagrodniczym, co ilustruje rozplanowanie wsi Glinnik w gm. Lubochnia (ryc. 20) ${ }^{45}$. Oddzielną kategorię stanowity siedliska w formie rzędówek, czego egzemplifikacją może być układ przestrzenny Feliksowa w gm. Poddębice, wsi powstałej w XIX w. w wyniku parcelacji gruntów folwarcznych należących do majątku Jeżew (ryc. 21) ${ }^{46}$. Powstające w tym czasie na dużą skalę rzędówki środkowopolskie cechował duży stopień zróżnicowania morfologicznego. Były wśród nich formy z jedna (ryc. 22) lub kilkoma osiami rozplanowania (ryc. 20), pozostającymi względem siebie w różnej konfiguracji przestrzennej - równoległej lub poprzecznej. Wsie nowego pochodzenia mogły być zabudowane jednostronnie, jak w przypadku Feliksowa (ryc. 21), lub obustronnie, w sposób naprzemianległy, co obserwujemy w rozplanowaniu wsi Ostrowsko w gm. Uniejów (ryc. 22), uregulowanej w dobrach majorackich rodziny Tollów ${ }^{47}$. Cechą charakterystyczną wsi poparcelacyjnych, szczególnie tych, w których procesy te następowały sukcesywnie, $\mathrm{w}$ wyniku długotrwałej wyprzedaży gruntów folwarcznych, było powstawanie siedlisk o charakterze kolonijnym i wtórnie rozproszonych. Część wsi starszego pochodzenia była ponadto rozbudowywana, a rezultatem zmian addytywnych było ewolucyjne przekształcanie niewielkich siedlisk w regularne układy wielodrogowe, przybierające formę określaną mianem kratownicy.

Analizowanym typom morfogenetycznym siedlisk towarzyszyły na obszarze środkowej Polski charakterystyczne formy rozłogów. $\mathrm{Na}$ szczególną uwagę zasługują układy poseparacyjne, folwarczno-chłopskie. Cechują się one zespoleniem w obrębie wsi wyraźnie rozdzielonych gruntów folwarcznych w formie blokowej i chłopskich w formie pasmowej w niwach, jak w przypadku Roszkowej Woli w gm. Rzeczyca (ryc. 19) ${ }^{48}$ lub docelowo w postaci nadziałów indywidualnych, jak we wsi Glinnik (ryc. 20). Były to formy wtórne (transformacyjne). Wspomnianym wcześniej rzędówkom poregulacyjnym towarzyszył pasmowy układ rozłogów, co ilustruje opisany wcześniej przykład Feliksowa (ryc. 21). W zależności od okresu i typu własności ziemskiej (wsi rządowych, majorackich, prywatnych) były to układy krótkolub długopasmowe oraz szeroko- lub wąskopasmowe. Najczęściej biegły prostopadle do drogi (ryc. 22), rzadziej ukośnie (ryc. 21), a niekiedy tworzyły układ radialny. Wspomnianym wcześniej kolonijnym siedliskom poparcelacyjnym towarzyszył natomiast blokowy układ rozłogów.

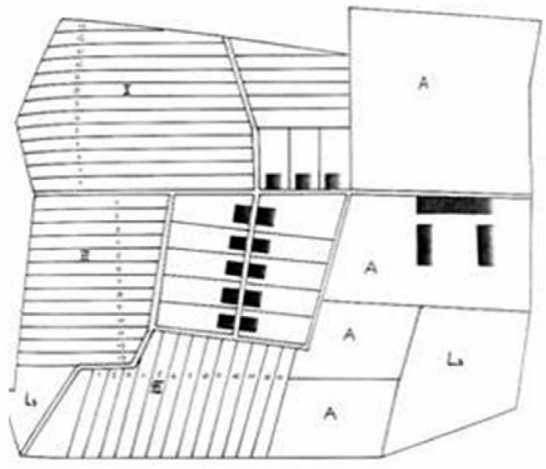

Ryc. 19. Roszkowa Wola. Odrys planu z $1862 \mathrm{r}$.

Źródto: APt, Zb. kart., sygn. 2115

\footnotetext{
${ }^{45}$ Po regulacji wsi Glinnik rozmierzono 854 morgi gruntów włościańskich oraz 392 morgi gruntów folwarcznych. SGKP, t. 2, s. 589.

${ }^{46}$ Według danych z 1881 r. wieś Feliksów obejmowała 390 mórg ziemi i 155 mieszkańców. Tamże, s. 380

${ }^{47}$ T. Figlus, Zróżnicowanie morfogenetyczne wsi na obszarze gminy Uniejów, „Biuletyn Uniejowski”, 3, 2014, s. 104-105.
}

${ }^{48}$ Na podstawie danych z 1888 r. wiemy, że Roszkowa Wola składała się z obejmującej 28 domów i 690 mórg ziemi wsi chłopskiej oraz folwarku zajmującego powierzchnię 584 mórg i 15 budynków. SGKP, t. 9, s. 808. 


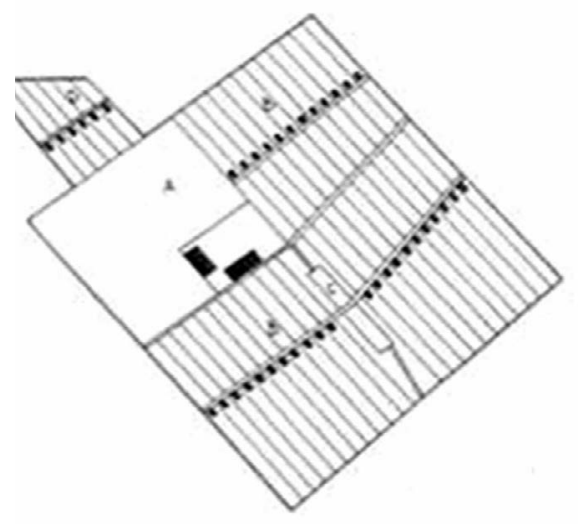

Ryc. 20. Glinnik. Odrys planu z 1856 r.

Źródto: APt, Zb. kart., sygn. 67

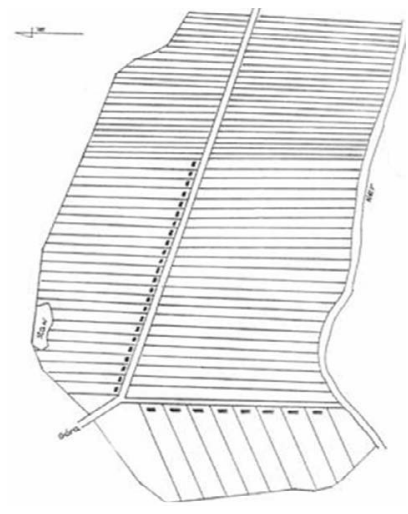

Ryc. 21. Feliksów. Odrys planu z 1837 r. Żródto: APt, Zb. kart., sygn. 2291

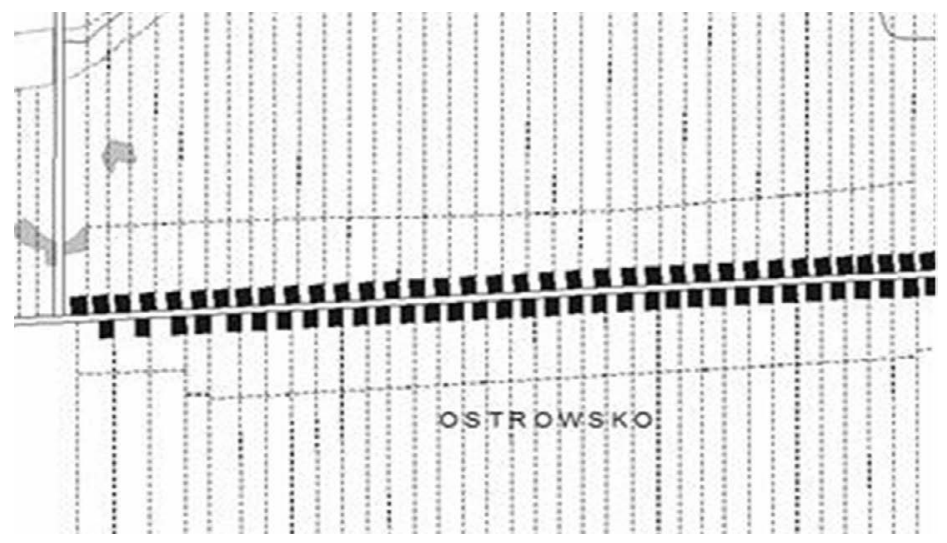

Ryc. 22. Ostrowsko. Odrys planu z 1861 r.

Źródto: AGAD, Zb. kart., sygn. 184-4 
Tab. 1. Zestawienie danych na temat wielkości i przynależności własnościowej wsi ujętych w artykule w 2. pot. XVI oraz 1. pot. XIX w. (1827 r.)

\begin{tabular}{|c|c|c|c|c|c|c|}
\hline \multirow{2}{*}{$\begin{array}{l}\text { Nazwa } \\
\text { miejscowości }\end{array}$} & \multicolumn{3}{|c|}{$\begin{array}{l}\text { Wielkość i przynależność własnościowa wsi } \\
\text { w 2. poł. XVI w. }\end{array}$} & \multicolumn{3}{|c|}{$\begin{array}{l}\text { Wielkość i przynależność własnościowa } \\
\text { wsi w 1. poł. XIX w. }\end{array}$} \\
\hline & liczba łanów & $\begin{array}{c}\text { liczba } \\
\text { osadników }\end{array}$ & typ własności & $\begin{array}{l}\text { liczba } \\
\text { domów }\end{array}$ & $\begin{array}{c}\text { liczba } \\
\text { mieszkańców }\end{array}$ & $\begin{array}{c}\text { typ } \\
\text { własności }\end{array}$ \\
\hline Biskupia Wola & 11 & 20 & kościelna & 48 & 308 & rządowa \\
\hline Borszewice & 9 & 11 & kościelna & 29 & 270 & rządowa \\
\hline Brodnia & 11 & 14 & monarsza & 70 & 439 & rządowa \\
\hline Bychlew & 12 & 22 & kościelna & 34 & 239 & rządowa \\
\hline Czastary & 13 & 20 & monarsza & 97 & 520 & rządowa \\
\hline Glinnik & 21,5 & 40 & monarsza & 51 & 353 & rządowa \\
\hline Gospodarz & - & - & - & 6 & 71 & rządowa \\
\hline Grzmiąca & 6 & 6 & szlachecka & 15 & 141 & prywatna \\
\hline Leśnik Olendry & - & - & - & 25 & 174 & prywatna \\
\hline Lubowidza & 2 & $\cdot$ & szlachecka & 12 & 124 & prywatna \\
\hline Makowiska & 9 & 25 & kościelna & 51 & 461 & rządowa \\
\hline Nowosolna & - & - & - & 86 & 1059 & prywatna \\
\hline Ostrowsko & 9 & 14 & kościelna & 53 & 520 & rządowa \\
\hline Pawlikowice & - & - & - & 56 & 401 & rządowa \\
\hline Piaski & 7,5 & $\cdot$ & szlachecka & 28 & 291 & prywatna \\
\hline Roszkowa Wola & 7 & 4 & szlachecka & 29 & 207 & prywatna \\
\hline Spycimierz & 6 & 6 & kościelna & 50 & 434 & rządowa \\
\hline Wiaderno & 11 & 25 & kościelna & 39 & 296 & rządowa \\
\hline Wola Mąkolska & 14 & 24 & kościelna & 58 & 310 & rządowa \\
\hline Zdziechów & 12 & 15 & kościelna & 40 & 322 & rządowa \\
\hline
\end{tabular}

Źródło: Dane z lat 1552-1553 lub 1576-1579 (dla wsi: Brodnia, Lubowidza, Piaski, Roszkowa Wola): „Polska XVI wieku pod względem geograficzno-statystycznym opisana przez Adolfa Pawińskiego", t. 2: „Wielkopolska”, Warszawa 1883 (Źródła Dziejowe, 13); tamże, t. 5: „Mazowsze”, Warszawa 1895 (Źródła Dziejowe, t. 16); „Tabella miast, wsi, osad Królestwa Polskiego z wyrażeniem ich położenia i ludności alfabetycznie ułożona w Biórze Kommissyi Rządowey Spraw Wewnętrznych i Policyi", t. 1-2, Warszawa 1827

\section{Rozkład przestrzenny typów rozplanowania wsi}

Wyobrażenie o częstości występowania wydzielonych typów morfogenetycznych daje analiza rozkładu przestrzennego form rozplanowania wsi wykonana $\mathrm{z}$ wykorzystaniem najstarszych map topograficznych badanego obszaru, tj. mapy Gilly'ego oraz tzw. mapy Kwatermistrzostwa $^{49}$. Zasięg wyznaczono na drodze przy-

${ }^{49}$ D. Gilly, Cron, Langner, Karte von Südpreußen, skala 1:50 000, Berlin 1793-1796, Preussischer Kulturbesitz-Staatsbibliothek zu Berlin, sygn. Kart N 14431; Топографическая карта Царства Польскаго, porządkowania poszczególnych wsi do układów uznanych za wzorcowe na podstawie przeprowadzonych badań szczegółowych. Wielkość i dostępność materiału kartograficznego wymusiła generalizację. Jeżeli chodzi o nieregularne wsie wczesnośredniowieczne, głównie małe owalnice, wsie drogowe i wielodrożnice, zauważono, że były to formy dominujące w peryferyjnych strefach obszaru badań, głównie w dolinach Warty

skala 1:126 000, Варшава 1839-[1843], Centralna Biblioteka Geografii i Ochrony Środowiska Instytutu Geografii i Przestrzennego Zagospodarowania PAN, sygn. C 542. 
i Pilicy oraz Bzury i Rawki ${ }^{50}$. Rozmieszczenie omawianych układów było zatem uwarunkowane w głównej mierze czynnikami fizjograficznymi. Stanowity one ponadto w znacznej mierze część zespołów osadniczych tworzonych przez poszczególne grody kasztelańskie ${ }^{51}$. Ulicówki i wsie placowe powstałe $\mathrm{w}$ procesie lokacji na prawie niemieckim tworzyły wyraźne skupiska, nawiązujące do obszarów podlegających ekspansji osadniczej w okresie wczesnohistorycznym. Zasięg występowania regularnych wsi średniowiecznych na obszarze środkowej Polski był przede wszystkim rezultatem oddziaływania czynników społeczno-własnościowych. Regularne wsie $\mathrm{z}$ tego okresu dominowaty bowiem w dobrach królewskich oraz różnych instytucji kościelnych ${ }^{52}$. Zauważono, że folwarki środkowopolskie nie miały zazwyczaj charakteru oddzielnych punktów osadniczych, lecz stanowity integralne komponenty morfologiczne wsi wcześniejszego pochodzenia. Ze względu na znaczne rozdrobnienie majątkowe szlachty nie tworzyły one zwartego kompleksu osadniczego i były równomiernie rozproszone $e^{53}$. Obszary koncentracji przestrzennej rzędówek bagiennych oraz innych układów wsi związanych z osadnictwem olęderskim i kolonizacją fryderycjańską zidentyfikowano głównie w części środkowej badanego obszaru, na którym ze względu na puszczański charakter w strefie wododziałowej kolonizacja wewnętrzna trwała najdłużej ${ }^{54}$. Lokalizacja wsi fryderycjańskich wykazuje ponadto silną korelację przestrzenną z dawną własnością królewską oraz kościelną, a więc dóbr przejętych na własność przez administrację pruską̧5. Dominację rzędówki z okresu wielkich reform agrarnych

\footnotetext{
${ }^{50}$ Zob. J. Dylik, Województwo, s. 84-93.

${ }^{51}$ Zob. A. Chmielowska, Osadnictwo w Polsce środkowej w okresie od potowy $X$ do potowy XIII w., „Prace i Materiaty Muzeum Archeologicznego w Łodzi. Seria Archeologiczna”, 22, 1975, s. 331-371. Por.: K. Modzelewski, Spór o gospodarcze funkcje organizacji grodowej. Najstarsze źródła i metody, „Kwartalnik Historii Kultury Materialnej”, 28, 1980, s. 87-101; K. Buczek, 0 ustroju społeczno-gospodarczym Polski wczesnofeudalnej (wiek X-XIII). Uwagi krytyczne na marginesie prac Karola Modzelewskiego, „Studia Historyczne”, 22, 1979, s. 663-690.

${ }^{52}$ S.M. Zajączkowski, Sieć osadnicza i struktura własnościowa osadnictwa dawnych ziem tęczyckiej i sieradzkiej w początkach XVI w., „Slavia Antiqua”, 19, 1972, s. 21-49.

${ }^{53}$ T. Sobczak, Zmiany w stanie posiadania dóbr ziemskich w województwie tęczyckim od XVI do XVIII wieku, „Roczniki Dziejów Społecznych i Go-
}

w XIX w. stwierdzono w części centralnej badanego obszaru, na wysoczyznach, które podlegały procesom osadniczym najpóźniej, oraz terenach będących w tym czasie własnością rządową i majoracką. Rozmieszczenie przysiółków - genetycznie związanych przede wszystkim z osadnictwem puszczańskim, częściowo olęderskim oraz wtórnym rozproszeniem poparcelacyjnym - nie miało zwartego charakteru. Były to głównie pojedyncze skupiska osadnicze w części centralnej, nawiązujące do terenów o największym zalesieniu do połowy XIX w., oraz w regonie rawskim, gdzie notowano największy udział szlachty zagrodowej.

\section{Wnioski końcowe}

Celem niniejszego artykułu było ukazanie wydzielonych typów morfogenetycznych wsi na obszarze środkowej Polski przez pryzmat wyselekcjonowanych przypadków. Zaproponowana typologia, bazująca na wykonanych uprzednio badaniach podstawowych, uwzględnia kryteria morfologiczno-genetyczne, w tym okres historyczno-osadniczy, w którym powstawały badane siedliska i rozłogi wiejskie, strukturę społeczno-agrarną wsi oraz formę siedlisk i rozłogów w powiązaniu z ich genezą. Wzięto także pod uwagę kryteria natury morfologiczno-morfometrycznej, w tym: cechy regularności rozplanowania, złożoności układu przestrzennego, stopień koncentracji zabudowy w przypadku siedlisk oraz cechy geometryczne siedlisk i rozłogów wiejskich. Pozwoliło to na identyfikację typów układów ruralistycznych według przyjętych kryteriów różnicujących w ujęciu morfochronologicznym (tab. 2). spodarczych", 17, 1955, s. 163-193; W. Szczygielski, Zmiany w stanie posiadania i w strukturze własnościowej szlachty powiatu wieluńskiego od połowy XVI do końca XVIII wieku, „Rocznik Łódzki”, 1, 1958, s. 259281; B. Baranowski, Rozwój gospodarki folwarczno-pańszczyźnianej w województwie tęczyckim i wschodniej części województwa sieradzkiego do połowy XVII wieku, „Zeszyty Naukowe Uniwersytetu Łódzkiego. Seria 1, Nauki Humanistyczno-Społeczne”, 1, 1955, s. 81-102.

${ }^{54}$ T. Figlus, Wsie olęderskie w Polsce Środkowej. Uwagi na temat zróżnicowania morfogenetycznego na tle rozwoju osadnictwa, „Rocznik Łódzki", 62, 2014, s. 143-159.

${ }^{55}$ Tenże, Znaczenie czynników prawno-politycznych w procesie ksztattowania wiejskiej sieci osadniczej dawnego województwa tęczyckiego i sieradzkiego w okresie przedrozbiorowym, w: Wybrane problemy badawcze geografii politycznej, red. M. Sobczyński, „Acta Universitatis Lodziensis, Folia Geographica Socio-Oeconomica", 17, 2014, s. 203-234. 
Tab. 2. Typy układów przestrzennych wsi środkowopolskich w ujęciu morfochronologicznym

\begin{tabular}{|c|c|c|}
\hline Okres morfogenetyczny & Typy siedlisk & Typy rozłogów \\
\hline $\begin{array}{l}\text { Okres wczesnośredniowieczny } \\
\text { (do połowy XIII w.) }\end{array}$ & $\begin{array}{l}\text { formy inicjalne, pierwotne: wsie } \\
\text { jednodworcze, nieregularne drogowe, } \\
\text { nieregularne placowe (okolnice, w tym } \\
\text { niepełne okolnice i małe, nieregularne } \\
\text { owalnice), rozdrożne i nieregularne } \\
\text { wielodrożnice (forma ewolucyjna) }\end{array}$ & $\begin{array}{l}\text { - nieregularne układy poloniarskie i } \\
\text { drobnoblokowe (formy pierwotne), } \\
\text { - układy drobnoblokowo-pasmowe (forma } \\
\text { ewolucyjna), } \\
\text { - układy drobnoniwowe nieregularne } \\
\text { (forma naśladowcza) }\end{array}$ \\
\hline $\begin{array}{l}\text { Okres lokacji na prawie niemieckim i } \\
\text { średniowiecznej regulacji } \\
\text { (do pocz. XVI w.) }\end{array}$ & $\begin{array}{l}\text { formy inicjalne lub transformacyjne, } \\
\text { naśladowcze: duże, regularne ulicówki } \\
\text { (w tym o niepełnej zabudowie), regularne } \\
\text { owalnice i inne wsie placowe (formy } \\
\text { pierwotne: trójkątne, prostokątne, } \\
\text { ryneczkowe), owalnice i ulicówki przyroste } \\
\text { w wielodrożnice (formy ewolucyjne) }\end{array}$ & $\begin{array}{l}\text { formy pierwotne (inicjalne, rzadziej } \\
\text { transformacyjne): } \\
\text { - układy niwowo-łanowe, } \\
\text { - układy leśno-łanowe typu nizinnego }\end{array}$ \\
\hline $\begin{array}{c}\text { Okres gospodarki folwarczno- } \\
\text {-pańszczyźnianej i osadnictwa } \\
\text { nowożytnego } \\
\text { (do pocz. XIX w.) }\end{array}$ & $\begin{array}{l}\text { wsie folwarczno-kmiece (forma wtórna, } \\
\text { ewolucyjna), folwarczno-zagrodnicze } \\
\text { (forma pierwotna), formy inicjalne, } \\
\text { naśladowcze: osiedla rozproszone } \\
\text { pierwotnie, nieregularne przysiółki } \\
\text { placowe i drogowe (wsie poleśne), } \\
\text { rzędówki bagienne i fryderycjańskie, } \\
\text { w tym wsie wielorzędowe (forma } \\
\text { pierwotna) }\end{array}$ & $\begin{array}{l}\text { - układy folwarczno-niwowe (forma } \\
\text { wtórna, ewolucyjna), } \\
\text { - układy folwarczno-wielkoblokowe } \\
\text { (forma inicjalna, pierwotna), } \\
\text { formy inicjalne, naśladowcze: } \\
\text { - układy blokowe i blokowo-pasmowe } \\
\text { nieregularne, } \\
\text { - układy blokowe regularne, } \\
\text { - układy szerokopasmowe, } \\
\text { - układy radialne (forma inicjalna, } \\
\text { pierwotna) }\end{array}$ \\
\hline $\begin{array}{l}\text { Okres wielkich reform agrarno- } \\
\text {-regulacyjnych (transformacji } \\
\text { morfologicznej) }\end{array}$ & $\begin{array}{l}\text { formy wtórne, transformacyjne: wsie } \\
\text { folwarczno-zagrodnicze sprzężone } \\
\text { z rzędówkami poregulacyjnymi, } \\
\text { samodzielne wsie folwarczno-zagrodnicze, } \\
\text { rzędówki poregulacyjne i poparcelacyjne, } \\
\text { wsie rozproszone wtórnie (kolonijne, } \\
\text { poparcelacyjne), wielodrożnice regularne } \\
\text { (forma ewolucyjna) }\end{array}$ & $\begin{array}{l}\text { formy wtórne, transformacyjne: } \\
\text { - układy folwarczno-chłopskie, } \\
\text { poseparacyjne (pasmowe sprzężone } \\
\text { z blokowymi); } \\
\text { - układy folwarczno-wielkoblokowe; } \\
\text { - regularne układy pasmowe i blokowe } \\
\text { - układy radialne o genezie poregulacyjnej } \\
\text { i poparcelacyjnej }\end{array}$ \\
\hline
\end{tabular}

Źródto: oprac. własne

Jednym z rezultatów badań był wniosek, że wsie środkowej Polski wykazują podobieństwo typologiczne do obszarów sąsiadujących, czego wynikiem było wydzielenie form uniwersalnych o szerokim spektrum przestrzennym występowania. Można wskazać również formy bardziej nietypowe, w znacznej mierze specyficzne dla badanego obszaru, np. zaprezentowane w tekście przypadki tzw. wsi ryneczkowych czy nizinnej odmiany układu leśno-łanowego. Należy do tego dodać przykłady rzadko spotykanych wsi wielofolwarcznych oraz kmieco-folwarcznych form separacyjnych z okresu poprzedzającego regulacje, jak również wyjątkowe pod względem rozplanowania układy przestrzenne wsi fryderycjańskich i olęderskich. Rozszerzają one funkcjonująca $w$ literaturze przedmiotu typologię zaproponowaną przez Halinę Szulc ${ }^{56}$ i świadczą o specyfice morfogenetycznej wsi

\footnotetext{
${ }^{56} \mathrm{H}$. Szulc, 0 typologiach morfologicznych osiedli wiejskich w Polsce, „Przegląd Geograficzny”, 48 (4), 1976, s. 627-636.
} 
wynikającej z przejściowości badanego obszaru, który rozwinął się na styku różnych regionów geograficzno-historycznych.

W wyniku przeprowadzonych badań ustalono, że obraz rozplanowania wsi środkowopolskich można uznać za znacząco zróżnicowany pod względem pochodzenia oraz cech morfologicznych, co widać głównie przez pryzmat badań rekonstrukcyjnych wsi z okresu poprzedzającego wielkie reformy agrarne w XIX w., gdyż procesy komasacyjno-separacyjne w znaczącym stopniu zubożyły pierwotny obraz ich rozplanowania. Dla poszczególnych okresów morfogenetycznych udało się zidentyfikować charakterystyczne formy siedlisk i rozłogów wiejskich. Okres wczesnofeudalny przyniósł na badanym obszarze powstanie osad jednodworczych, a następnie nieregularnych wsi drogowych, rozdrożnych, okolnic, owalnic i wielodrożnic. Towarzyszyły im początkowo układy poloniarskie rozłogów, a następnie układy blokowe, blokowo-pasmowe i pseudoniwowe. W okresie pełnego i późnego średniowiecza wśród siedlisk wiejskich identyfkowano głównie regularne ulicówki, owalnice $\mathrm{i}$ inne wsie placowe (w tym tzw. ryneczkowe) oraz wsie cechujące się złożoną formą rozpla- nowania. Dominowały wtedy rozłogi niwowo-łanowe, podporządkowane trójpolówce, a w nielicznych przypadkach również odmiana nizinna układu leśno-łanowego. Z okresu gospodarki opartej na pańszczyźnie rozpoznano wsie folwarczno-kmiece i folwarczno-zagrodnicze, $\mathrm{z}$ przemieszaną własnością folwarczną i chłopską lub, rzadko, z cechami częściowej separacji rozłogów. Pojawiały się licznie przysiółki i osady rozproszone, $\mathrm{w}$ tym poleśne, młyńskie, karczmarskie i protoprzemysłowe. Wsie olęderskie i fryderycjańskie wykazywały na badanym obszarze charakter osad wtórnie zasiedlonych lub założonych in cruda radice. Ich geneza była silnie związana $\mathrm{z}$ cechami morfologicznymi. Zidentyfikowano przede wszystkim rzędówki bagienne z pasmowym układem pól, wsie rozproszone z blokowym układem pól oraz specyficzne układy o złożonym modelu rozplanowania (np. wsie wieloboczne). Podobne zależności wykrytowodniesieniudowsiukształtowanychwwyniku reform agrarnych $\mathrm{w}$ XIX w. W zależności od okresu powstania wykazały one cechy rzędówek poregulacyjnych lub kolonii poparcelacyjnych o zróżnicowanym charakterze rozplanowania siedlisk i rozłogów.

\section{Bibliografia}

Arnold S., Geografia historyczna Polski, Warszawa 1951.

Baranowski B., Gospodarstwo chtopskie i folwarczne we wschodniej Wielkopolsce w XVIII wieku, Warszawa 1958.

Baranowski B., Rozwój gospodarki folwarczno-pańszczyźnianej w województwie tęczyckim $i$ wschodniej części województwa sieradzkiego do potowy XVII wieku, „Zeszyty Naukowe Uniwersytetu Łódzkiego. Seria 1, Nauki Humanistyczno-Społeczne”, 1, 1955, s. 81-102.

Baruch M., Rzgów i wsie okoliczne: monografia historyczna dawnych dóbr kapituty krakowskiej $w$ Sieradzkim i Eęczyckim, Warszawa 1903.

Bortkiewicz F., Nadziaty i powinności chtopów pañszczyźnianych $w$ dobrach prywatnych Królestwa Polskiego, Warszawa 1958.
Buczek K., O ustroju spoteczno-gospodarczym Polski wczesnofeudalnej (wiek X-XIII). Uwagi krytyczne na marginesie prac Karola Modzelewskiego, „Studia Historyczne”, 22, 1979, s. 663-690.

Burszta J., Od osady stowiańskiej do wsi wspótczesnej. O tworzeniu się krajobrazu osadniczego ziem polskich i rozplanowaniu wsi, Wrocław 1958.

Burszta J., Osadnictwo i ksztatty wsi, w: Kultura ludowa Wielkopolski, t. 1, red. J. Burszta, Poznań 1960.

Chańko J., Szymczak J., Dzieje polityczne i struktury terytorialno-administracyjne, w: Zarys monografii województwa tódzkiego, red. S. Liszewski, Łódź 2001, s. 135-153.

Chmielowska A., Badania nad wczesnośredniowiecznym osadnictwem grodowym i jego wiejskim zapleczem na obszarze Polski środkowej, „Acta Universitatis Lodziensis. Seria 1", 36, 1979, s. 35-51. 
Chmielowska A., Osadnictwo w Polsce środkowej $w$ okresie od potowy X do potowy XIII w., „Prace i Materiały Muzeum Archeologicznego w Łodzi. Seria Archeologiczna”, 22, 1975, s. 331-371.

Chomać B., Struktura agrarna Królestwa Polskiego na przetomie XIX i XX wieku, Warszawa 1970.

Dobrowolska M., Procesy osadnicze w dorzeczu Wistoki i Biatej Dunajcowej w tysiącleciu, Kraków 1985 (Prace Monograficzne WSP, 69).

Dylik J., Rozwój osadnictwa w okolicach Łodzi, Łódź 1948 (Acta Geographica Lodziensia, 2).

Dylik J., Województwo ze stolica bez antenatów. Geografia historyczna województwa tódzkiego, Łódź 1971.

Figlus T., Morfogeneza wsi na obszarze Polski Środkowej, rozprawa doktorska, mps w Bibliotece Uniwersytetu Łódzkiego, Łódź 2013.

Figlus T., Rozwój uktadu ruralistycznego Spycimierza na tle dziejów osadnictwa w świetle badań geograficzno-historycznych $i$ archeologicznych, „Biuletyn Uniejowski", 4, 2015, s. 73-94.

Figlus T., Uktady przestrzenne wsi folwarcznych $w$ Polsce. Typy morfogenetyczne i ochrona dziedzictwa ruralistycznego, w: Rozwój zrównoważony regionów Polski, red. W. Wysota i in., Toruń 2011, s. 269-278.

Figlus T., Wsie olęderskie w Polsce Środkowej. Uwagi na temat zróżnicowania morfogenetycznego na tle rozwoju osadnictwa, „Rocznik Łódzki”, 62, 2014, s. 143-159.

Figlus T., Wybrane aspekty zastosowania wielkoskalowych źródet kartograficznych $w$ badaniach morfogenetycznych wsi, w: Dawne mapy jako źródta historyczne, red. B. Konopska i in., Warszawa 2012, s. 91-103 (Biblioteka Polskiego Przeglądu Kartograficznego, 3).

Figlus T., Wybrane zagadnienia morfogenetyczne owalnic w Polsce Srodkowej, w: Wspótczesne zagadnienia, problemy $i$ wyzwania $w$ badaniach geograficznych, t. 2, red. T. Wiskulski, M. Pilarski, Gdańsk 2013, s. 141-153.

Figlus T., Znaczenie czynników prawno-politycznych $w$ procesie ksztattowania wiejskiej sieci osadniczej dawnego województwa tęczyckiego i sieradzkiego w okresie przedrozbiorowym, w: Wybrane problemy badawcze geografii politycznej, red. M. Sobczyński, „Acta Universitatis Lodziensis, Folia Geographica Socio-Oeconomica”, 17, 2014, s. 203-234.
Figlus T., Zróżnicowanie morfogenetyczne wsi na obszarze gminy Uniejów, „Biuletyn Uniejowski”, 3, 2014, s. 85-110.

Golachowski S., Kostrubiec B., Zagożdżon A., Metody badań geograficzno-osadniczych, Warszawa 1974.

Goldberg J., Osadnictwo olęderskie $w$ dawnym województwie tęczyckim i sieradzkim, „Zeszyty Naukowe Uniwersytetu Łódzkiego. Seria 1. Nauki Humanistyczno-Społeczne", 5, 1957, s. 67-110.

Groniowski K., Kwestia agrarna w Królestwie Polskim 1871-1914, Warszawa 1966.

Hannerberg D., Solskifte and Older Methods of Partitioning Arable Land in Central Sweeden during the Middle Ages, w: Géographie et histoire agraires, Actes du colloque international organisé par la Faculté de Lettres de l'Université de Nancy, ed. X. De Planhol, [b.m.w.] 1959, s. 245-259 (Annales de l'Est. Mémoire, 21).

Heike O., 150 Jahre Schwabensiedlungen in Polen 1795-1945, Leverkusen 1979.

Kamińska J., Grody wczesnośredniowieczne Polski środkowej na tle osadnictwa, Łódź 1953.

Kiełczewska-Zaleska M., O powstaniu i przeobrażeniu ksztattów wsi Pomorza Gdańskiego, Warszawa 1956 (Prace Geograficzne, 5).

Korytkowski J., Arcybiskupi gnieźnieńscy: prymasowie i metropolici polscy od roku 1000 az do roku 1821, t. 2, Poznań 1888.

Kossmann E.O., Die Deutschen in Polen seit der Reformation. Historisch-geographische Skizzen: Siedlung, Sozialstruktur, Wirtschaft, Marburg-Lahn 1978.

Kossmann E.O., Deutschrechtliche Siedlung in Polen, dargestellt am Lodzer raum, Posen-Leipzig 1939.

Koter M., Fizjonomia, morfologia i morfogeneza miasta. Przeglad rozwoju oraz próba uściślenia pojęć, „Zeszyty Naukowe Uniwersytetu Łódzkiego. Seria 2, Nauki Matematyczno-Przyrodnicze", 55, 1974, s. 3-16.

Koter M., Od fizjonomii do morfogenezy i morfologii porównawczej. Podstawowe zagadnienia teoretyczne morfologii miast, w: Zagadnienia geografii historycznej osadnictwa $w$ Polsce. Materiaty konferencyjne, red. M. Koter, J. Tkocz, Toruń-Łódź 1994, s. 23-32.

Koter M., Rola wiejskich elementów morfologicznych $w$ procesie ksztattowania uktadu przestrzennego Łodzi, w: Zagadnienia geografii historycznej osadnictwa w Polsce, red. M. Koter, J. Tkocz, Toruń-Łódź 1994, s. 63-88. 
Kowalik-Bodzak D., Wptyw podziatu spadkowego, komasacji $i$ parcelacji na zmiane uktadów przestrzennych wsi $w$ powiecie putawsim od potowy XIX w., Warszawa 1964, s. 97-152 (Dokumentacja Geograficzna, 4).

Kozierowski S., Badania nazw topograficznych na obszarze dawnej wschodniej Wielkopolski, t. 2, Poznań 1928.

Krenzlin A., Dorf, Feld und Wirtschaft im Gebiet der großen Täler und Platten östlich der Elbe, Remagen 1952.

Kukulski J., Przemiany na wsi powiatu piotrkowskiego $w$ latach 1793-1918. Studia i materiaty, Piotrków Trybunalski 2005.

Labuda G., Uwagi o przedmiocie i metodzie geografii historycznej, „Przegląd Geograficzny”, 25 (1), 1953, s. 5-56.

Lalik T., Przeglad badan nad historia rozplanowania osad wiejskich w Polsce, Warszawa 1953 (IUA. Seria Prac Własnych, 11).

Matuszewski J., Nazwy administracyjne osad lokowanych na prawie niemieckim, Łódź 1974.

Mazowsze $w$ drugiej potowie XVI w., cz. 1-2, red. W. Pałucki, oprac. A. Dunin-Wąsowiczowa i in., Warszawa 1973 (Atlas historyczny Polski. Mapy szczegółowe XVI wieku, 7).

Modzelewski K., Spór o gospodarcze funkcje organizacji grodowej. Najstarsze źródta $i$ metody, „Kwartalnik Historii Kultury Materialnej”, 28, 1980, s. $87-101$.

Nowak T., Wtasność ziemska w ziemi tęczyckiej w czasach Wtadystawa Jagietty, Łódź 2003.

Ohryzko-Włodarska C., Przemiany na wsi Królestwa Polskiego w latach 1846-1870. Na przyktadzie powiatu brzezińskiego, Warszawa 1972.

Podwińska Z., Gospodarstwo wiejskie w okresie wczesnofeudalnym (V w.-poczatek XII wieku), w: Zarys historii gospodarstwa wiejskiego $w$ Polsce, t. 1, red. J. Leskiewiczowa, Warszawa 1964, s. 183-264.

Podwińska Z., Zmiany form osadnictwa wiejskiego na ziemiach polskich we wcześniejszym średniowieczu: źreb, wies, opole, Warszawa 1971.

Prochownik A., Przemiany struktury osadniczo-agrarnej wsi powiatu proszowickiego od potowy XIX wieku do 1960 r. (na wybranych poktadach), Warszawa 1965 (Dokumentacja Geograficzna, 6).

Rippel J., Eine statistische Methode zur Untersuchung von Flur-und Ortsentwicklung, „Geografiska Annaler”, 43 (1-2), 1961, s. 252-263.
Rosin R., Rozwój terytorialno-polityczny dawnych ziem województwa tódzkiego, „Prace i Materiały Muzeum Archeologicznego w Łodzi. Seria Archeologia”, 22, 1975, s. 411-433.

Rosin R., Stownik historyczno-geograficzny ziemi wieluńskiej w'rredniowieczu, Warszawa 1963.

Rosin R., Ziemia Wieluńska XII-XVI w. Studia z dziejów osadnictwa, Łódź 1961.

Rusiński W., Osady tzw. „Olędrów” w dawnym woj. poznańskim, Poznań-Kraków 1947.

Sheppard J., Metrological Analysis of Regular Village Plans in Yorkshire, „The Agricultural History Review”, 22 (2), 1974, s. 118-135.

Stownik geograficzny Królestwa Polskiego i innych krajów stowiańskich, t. 1-16, wyd. B. Chlebowski, F. Sulimierski, W. Walewski, Warszawa 1880-1902.

Sobczak T., Zmiany w stanie posiadania dóbr ziemskich $w$ województwie tęczyckim od XVI do XVIII wieku, „Roczniki Dziejów Społecznych i Gospodarczych”, 17, 1955, s. 163-193.

Stankiewicz Z., Zasady uwtaszczenia chtopów w Królestwie Polskim, w: Studia i materiaty do dziejów Łodzi i okręgu tódzkiego. Uwtaszczenie chtopów i mieszczan rolników, red. H. Brodowska, Łódź 1966, s. 23-82.

Szczygielski W., Zmiany w stanie posiadania i w strukturze wtasnościowej szlachty powiatu wieluńskiego od potowy XVI do końca XVIII wieku, „Rocznik Łódzki”, 1, 1958, s. 259-281.

Szulc H., Badania geograficzno-historyczne osadnictwa wiejskiego w Polsce, „Przegląd Geograficzny”, 55 (3), 1983, s. 647-661.

Szulc H., Geografia historyczna osadnictwa wiejskiego w Polsce - kierunki i metody badań oraz perspektywy na przysztość, „Przegląd Geograficzny”, 75 (3), 2003, s. 335-350.

Szulc H., Morfogenetyczne typy osiedli wiejskich na Pomorzu Zachodnim, Wrocław 1988 (Prace Geograficzne, 149).

Szulc H., Morfogeneza osiedli wiejskich w Polsce, Wrocław 1995 (Prace Geograficzne, 163).

Szulc H., O typologiach morfologicznych osiedli wiejskich w Polsce, „Przegląd Geograficzny”, 48 (4), 1976, s. 627-636.

Szulc H., Osiedla podwroctawskie na początku XIX w., Wrocław 1963 (Monografie Śląskie, 5).

Szulc H., Problem generalizacji uktadów przestrzennych wsi, „Kwartalnik Historii Kultury Materialnej”, 27 (4), 1969, s. 721-733. 
Szulc H., Typy wsi Ślaska Opolskiego na poczatku XIX w. i ich geneza, Warszawa 1968 (Prace Geograficzne, 66).

Szurowa B., Przemiany osadnictwa wiejskiego na Kielecczyźnie $w$ dobie przeduwtaszczeniowej. Zmiany uktadu przestrzennego wsi, Kielce 1995.

Szurowa B., Zmiany uktadu przestrzennego wsi kieleckiej od XIII do potowy XX wieku, Kielce 1998.

Szymczakowa A., Szlachta sieradzka w XV wieku: magnifici et generosi, Łódź 1998.

Śmiałowski J., Zmiana $w$ nadziałach chtopów $w$ dobrach prywatnych powiatu sieradzkiego $w$ pierwszej potowie XIX w., „Rocznik Łódzki”, 6, 1960, s. $145-172$.

Tkocz J., Organizacja przestrzenna wsi w Polsce, Katowice 1998 (Prace Naukowe Uniwersytetu Śląskiego, 1734).

Tkocz J., Uwagi metodyczne o generalizacji uktadów przestrzennych jednostek osadniczych $w$ badaniach geograficzno-historycznych, w: Niektóre teoretyczne problemy rolniczego osadnictwa, red. J. Tkocz, Opole 1971.

Tyszkiewicz J., Geografia historyczna. Zarys problematyki, Warszawa 2014.

Warężak J., Osadnictwo kasztelanii towickiej 1136 1847, cz. 1, Łódź 1952.

Warężak J., Stownik historyczno-geograficzny Księstwa Łowickiego, cz. 2, z. 1, Wrocław-Warszawa-Kraków 1961.

Warężak J., Stownik historyczno-geograficzny Księstwa Eowickiego, cz. 2, z. 2, Łódź 1967.

Województwo sandomierskie $w$ drugiej potowie XVI w., cz. 1-2, red. W. Pałucki, oprac. K. Chłapowski i in., Warszawa 1993 (Atlas historyczny Polski. Mapy szczegółowe XVI wieku, 2).
Województwo sieradzkie $i$ województwo tęczyckie $w$ drugiej potowie XVI w., cz. 1-2, red. H. Rutkowski, oprac. K. Chłapowski i in., Warszawa 1998 (Atlas historyczny Polski. Mapy szczegółowe XVI wieku, 5).

Wojtkowiak S., Badania nad ksztattami osiedli wiejskich ziemi tęczyckiej $w$ średniowieczu, rozprawa doktorska, mps w Bibliotece Uniwersytetu Łódzkiego, Łódź 1962.

Woźniak K.P., Niemieckie osadnictwo wiejskie między Prosna a Pilica $i$ Wista od lat 70. XVIII wieku do 1866 r. Proces i jego interpretacje, Łódź 2013.

Zaborski B., O ksztattach wsi $w$ Polsce $i$ ich rozmieszczeniu, Kraków 1926 (Prace Komisji Etnograficznej PAU, 1).

Zajączkowski S., Studia nad osadnictwem dawnych ziem teczyckiej i sieradzkiej $w$ XII-XIV w. Uwagi $i$ spostrzeżenia, „Studia z Dziejów Osadnictwa”, 4, 1966, s. 2-85.

Zajączkowski S., Zajączkowski S.M., Materiaty do stownika geograficzno-historycznego dawnych ziem tęczyckiej i sieradzkiej do 1400 roku, cz. 1-2, Łódź 1966-1970.

Zajączkowski S.M., O lokacjach wsi na prawie niemieckim $w$ Eęczyckiem i Sieradzkiem od końca XIV do początków XVI wieku, Łódź 1974.

Zajączkowski S.M., Początki folwarku w ziemiach tęczyckiej i sieradzkiej (do początków XVI w.), „Roczniki Dziejów Społeczno-Gospodarczych”, 31, 1970, s. $1-43$.

Zajączkowski S.M., Sieć osadnicza i struktura wtasnościowa osadnictwa dawnych ziem tecczyckiej i sieradzkiej w początkach XVI w., „Slavia Antiqua”, 19, 1972, s. 21-49. 


\section{Morphogenetic Types of Rural Settlements in Central Poland}

\section{Summary}

Historico-geographical analysis of the layouts of villages in central Poland made it possible to distinguish the morphogenetic types of rural settlements characteristic of the specified historical periods. On the basis of the historical topographic maps, it is also possible to describe the features of spatial distribution of the morphogenetic types of villages for the investigated area. Central Poland presents a very diversified morphogenetic picture of villages, which results from a great number of complex historical and socio-economic processes, as well as from varied geographical conditions. Four main historical periods were distinguished, during which the following characteristic morphogenetic types of villages were established:

1. irregular medieval villages which did not undergo regulation in the Middle Ages;

2. regular medieval villages located on German Law;

3. newer settlements founded in the Modern Period (e.g. manorial layouts and villages connected with the so-called olęder settlement and Frederician colonization);

4. villages formed in the process of regulation and parcellation in $19^{\text {th }} \mathrm{c}$.

The villages form Early Middle Ages developed in an evolutionary way, were not regulated, and adapted well to the local topographic position. Among the villages with irregular habitats from this period the following types can be singled out: road villages, little green villages (small oval) and circular villages; cross-road villages and multi-road villages. The land was divided into numerous small fields, irregular in shape. The layout of fields in these villages takes the form of blocks, block-strips and irregular small fields.

Two distinct processes were taking place in the Middle Ages: foundation of the new villages on the so-called in cruda radice, and regulation of the villages already existing according to the German law. These villages were built mostly on the Church land of the cloisters and bishops, as well as on land belonging at that time to the Duke. The generally accepted types of villages founded on the German law are: large regular street villages and regular green villages (with oval or rectangular square). Regular field patterns in those villages were organized in the open-field patternadapted to the three-field rotation system.

Within the group of villages of later origin, established between the $16^{\text {th }} \mathrm{c}$. and the $1^{\text {th }}$ half of $19^{\text {th }}$ c., the following types were distinguished: manors and marshy row villages (the so-called olęder or Frederician colonies and other colonies - the so-called forest settlements). In Modern Period one can identify mostly the manor-peasant village with a complex of manor buildings and peasant homesteads. Manor and peasant fields intermingled and were cultivated by means of the three-field system. Rarely can one observe manor villages which included only the manor complex with crofters' small holdings and where fields were consolidated into large blocks. In the $18^{\text {th }} \mathrm{c}$. planned villages were built again, which was connected with the Frederician and the so-called olęder colonization. Marshy row villages located on clearings can be distinguished, which represented a different spatial pattern with regard to the economic functions of their population. Agricultural colonies were mostly regular street villages, densely built-up. The pattern of the fields took the form of regular, schematic, broad stripes, belonging to separate owners.

The $19^{\text {th }} \mathrm{c}$. marks the turning point in the development of the forms of rural settlement. The ancient spatial settings of villages have changed mostly in connection with the transformation of the socio-economic life of the countryside, in particular the enfranchisement of peasants, the parcellation of manors and field consolidation, the disappearance of the threefield rotation system, and the introduction of new techniques of cultivation. In the manor-peasant village one can observe the process of separation of manor and peasant land. In 
the context of parceling-out it is possible to distinguish row villages with fields in the form of ownership stripes, perpendicular to the road and dispersed settlement with block system of fields.

The irregular layouts of villages from the Middle Ages were formed mostly in the peripheries of central Poland, in the valleys of the Warta, Bzura and Pilica rivers. Compact settlement regions of regular villages, founded during the medieval colonization, have been identified in the area of former ecclesiastical or royal estates, where proprietors were interested in location of villages based on the German law. Manors developed mainly inside the villages, and they did not form separate settlement units and morphogenetic zones. Forest colonies and marshy row villages appear as small enclaves throughout the whole investigated area, especially in the central part of region, because they were mostly founded on clearings, areas not cultivated before, on poor soils and in forests.

Słowa kluczowe: osadnictwo wiejskie, morfogeneza, środkowa Polska

Keywords: rural settlement, morphogenesis, central Poland

dr Tomasz Figlus - naukowo związany z Katedrą Geografii Politycznej, Historycznej i Studiów Regionalnych (Wydział Nauk Geograficznych Uniwersytetu Łódzkiego).

Zainteresowania badawcze: geografia historyczna osadnictwa wiejskiego, w tym studia nad morfogenezą i dziedzictwem kulturowym obszarów wiejskich (e-mail: tomasz.figlus@gmail.com) 